\title{
MANUEL DE DESSINS POUR CROCHET
}

\section{SMITHSONLAN LIBRARIES}


\begin{tabular}{c}
$\bar{c}$ \\
$\bar{c}$ \\
\hline
\end{tabular}

$S$ SMITHSONIAN

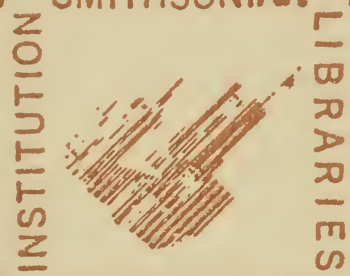

NI NVINOSHLIWS

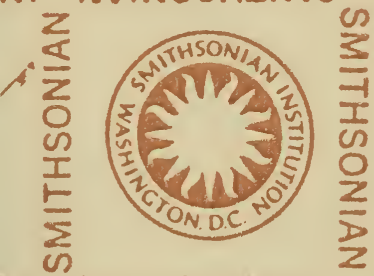

INSTITUTION

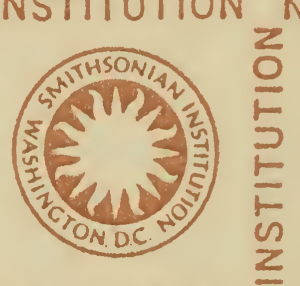

NOIIR IIISN

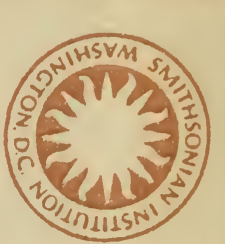

0
20
2
$m$

(n)

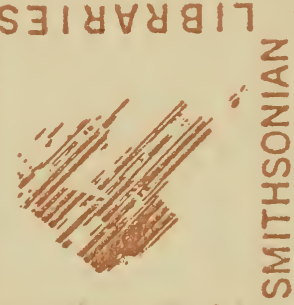

$\frac{2}{2}$

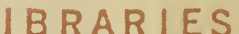

3
$\frac{1}{1}$
$\frac{1}{0}$
$\frac{2}{2}$

SMITHSONIA
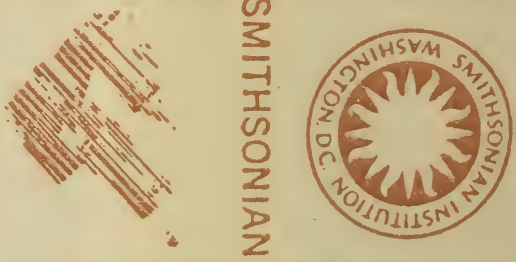

NHINOSHIIW

$\frac{z}{0}$

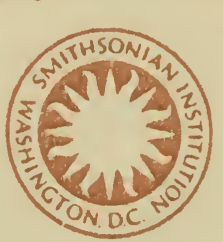

$\omega$
$\alpha$
$\alpha$
$\alpha$
$\infty$

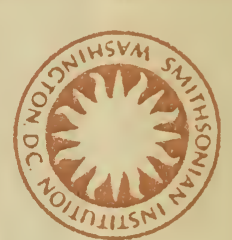

2
0
-1
-1
-1
$\frac{0}{2}$

$5318 \forall y 817$

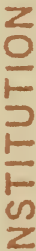

(s)

S
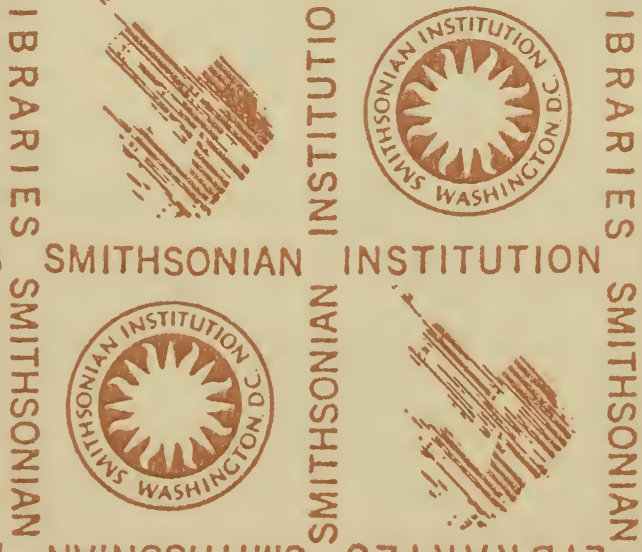

INSTITUTION
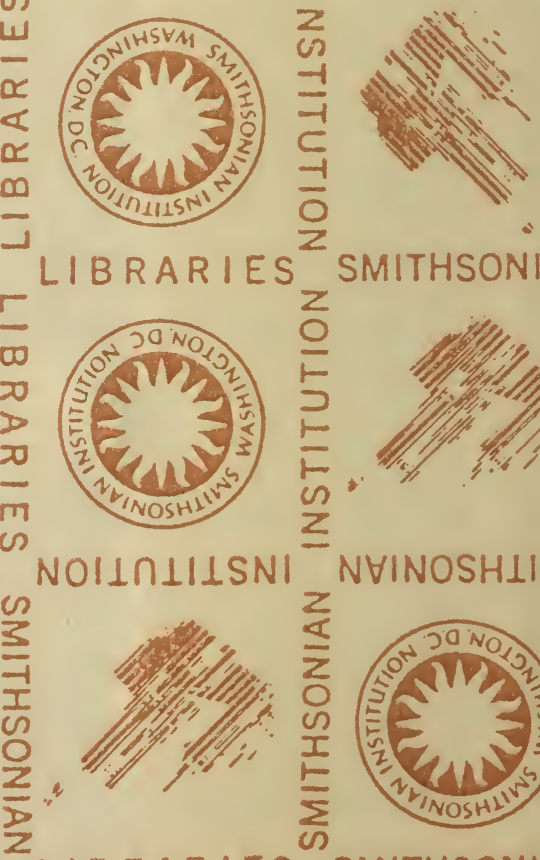

SMITHSONIA

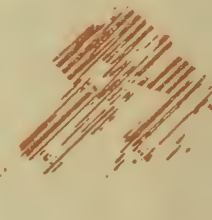

NOILRLILSNI

NHINOSHLIW
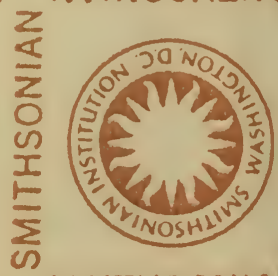


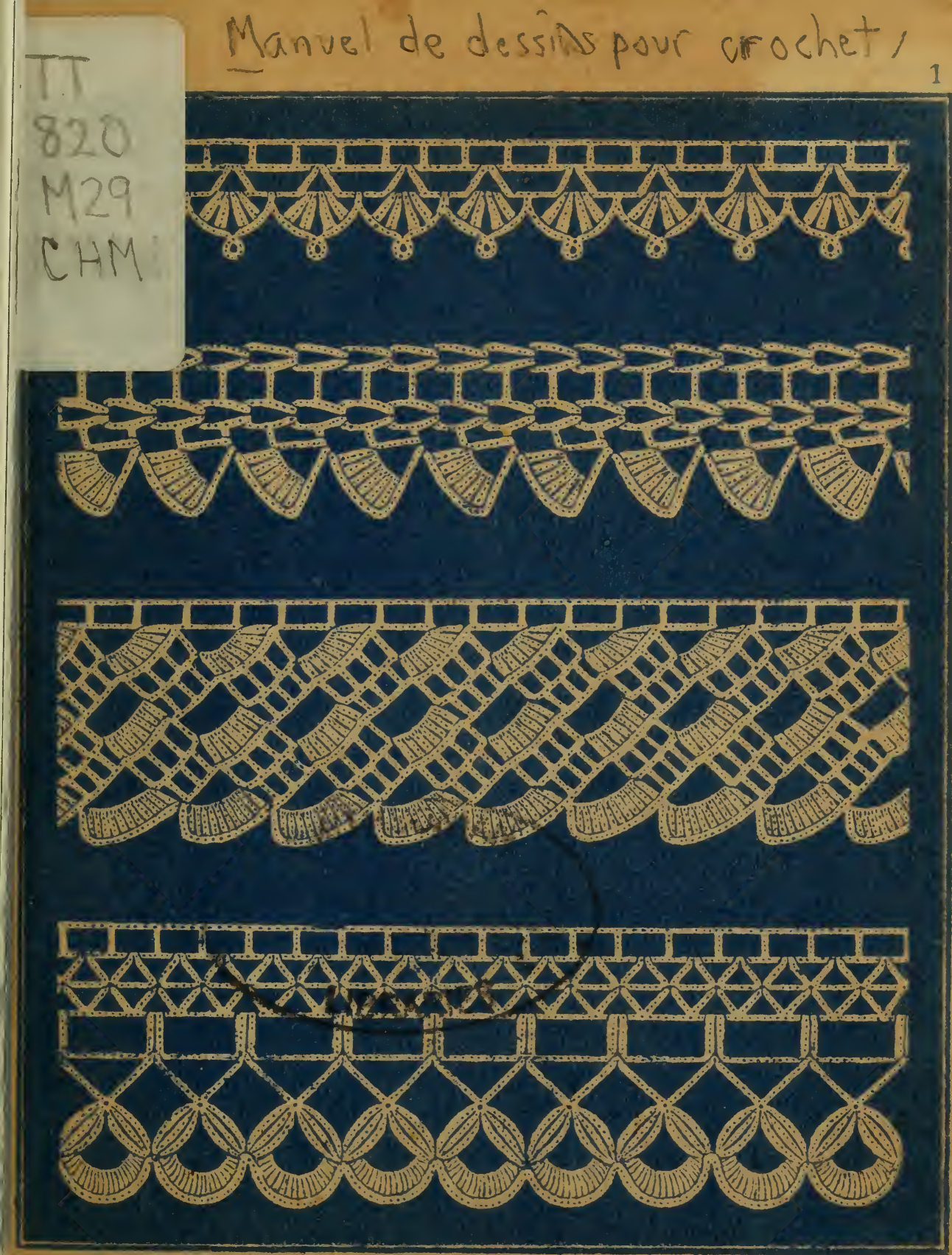

N. ALEXANDRE \& C!" Maurice LAJEUnESSE, Suc?,Euit?. Rue S! Mantin,24I,PARIS. 



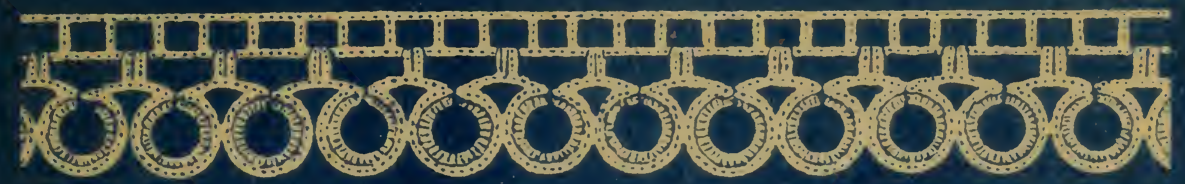

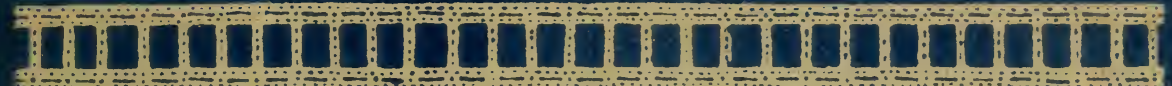
Bopundon

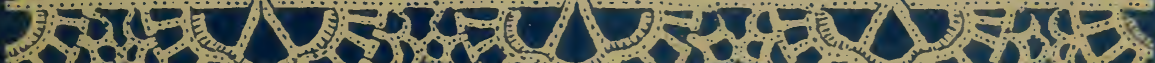

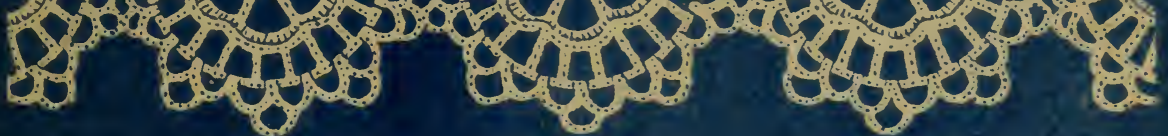

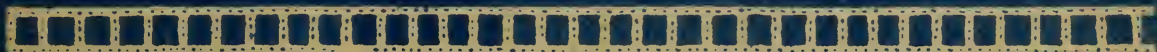

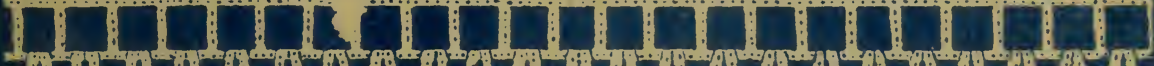
numinatom

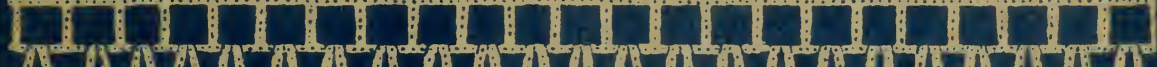
S ANa ISt a

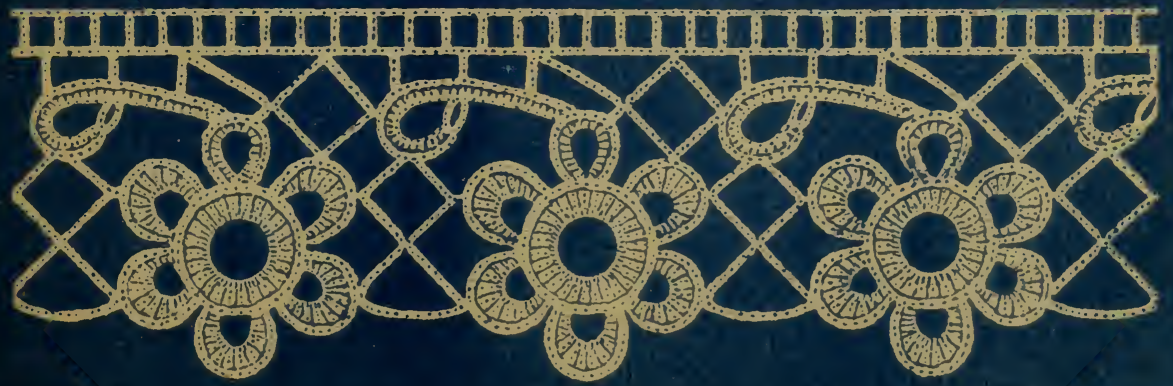





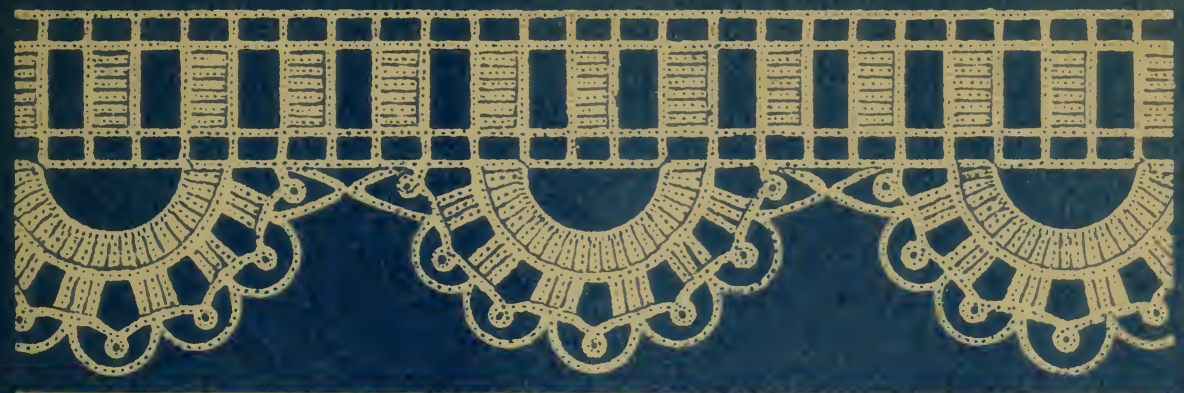

0 and

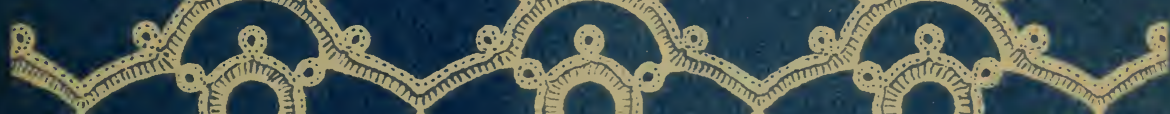

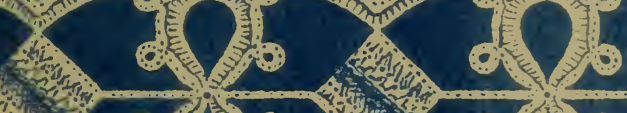

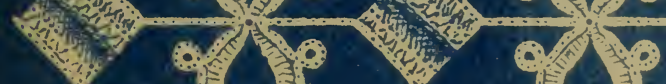
6)

前-

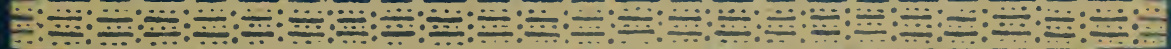

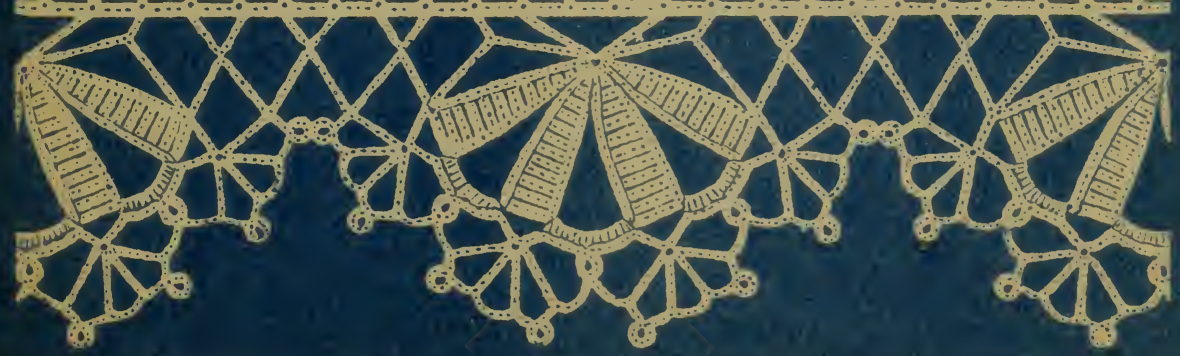




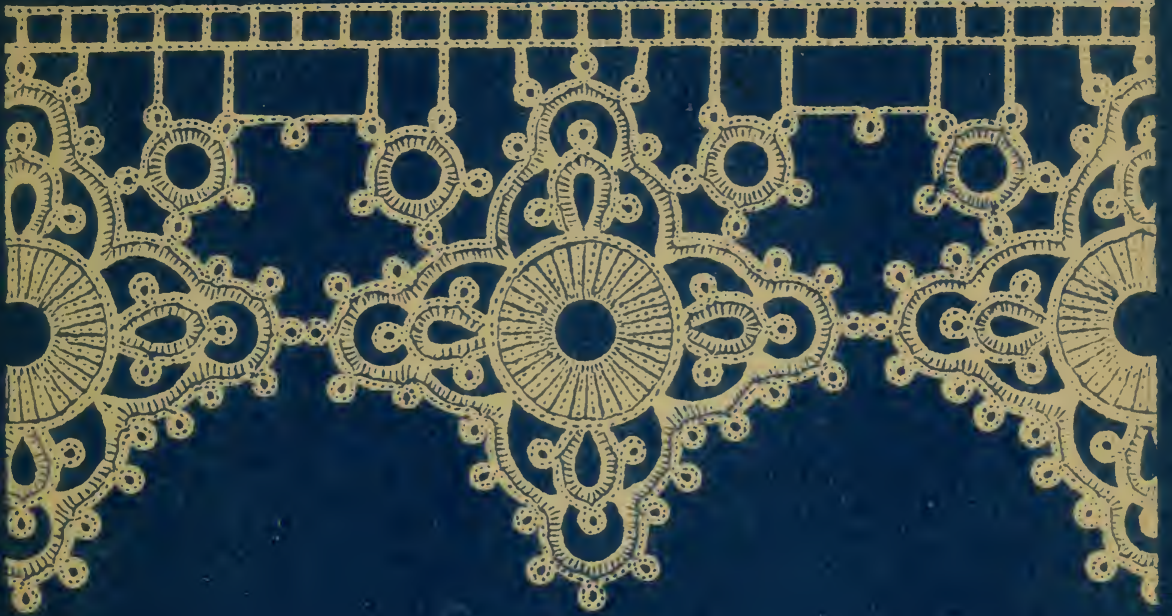

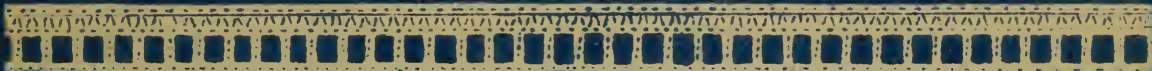

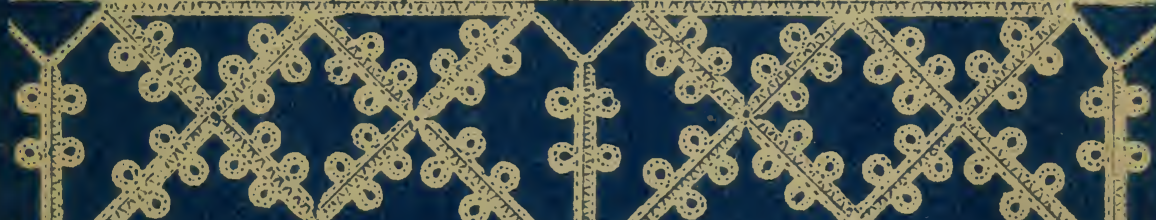

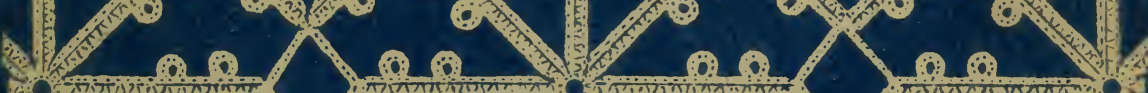

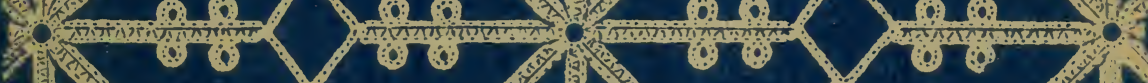
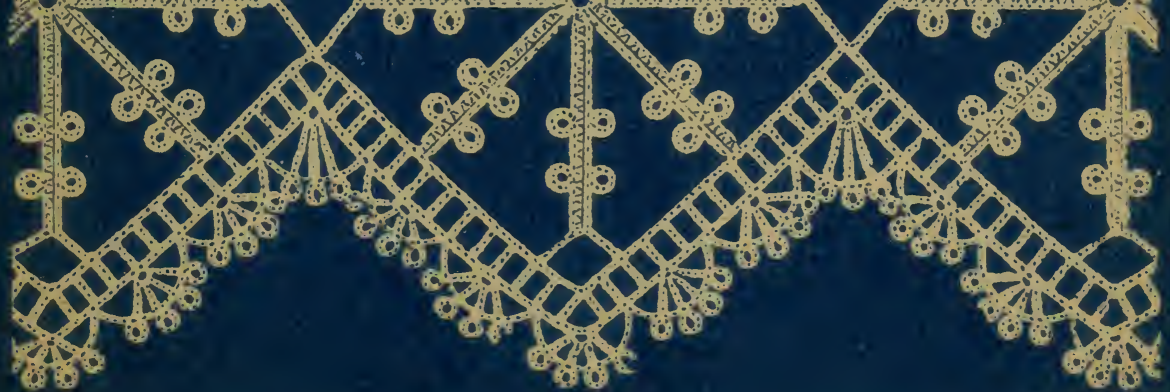



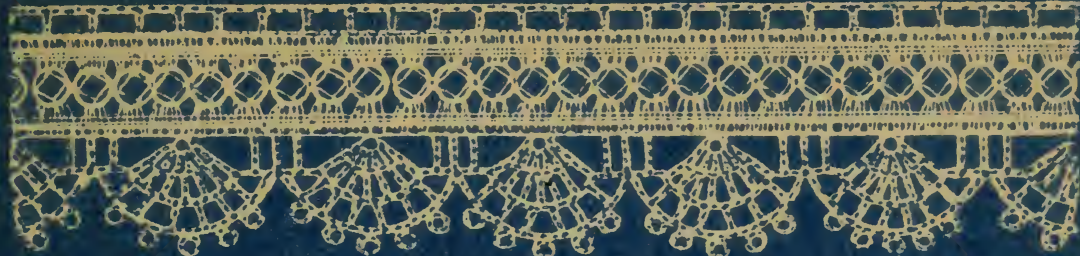

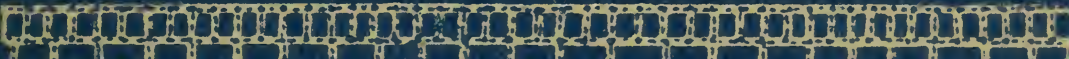

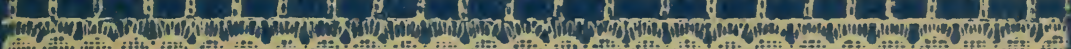

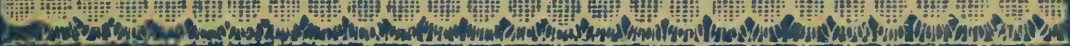

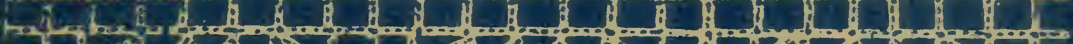

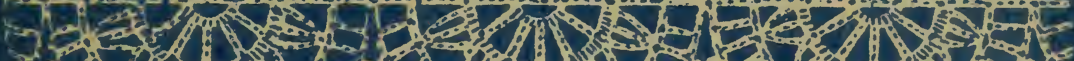

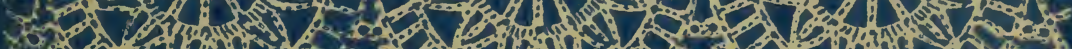
1.6. 6.

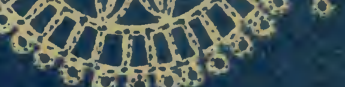

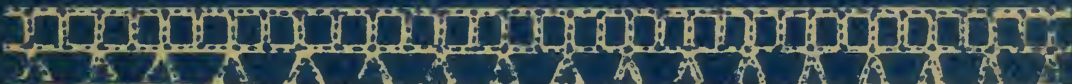

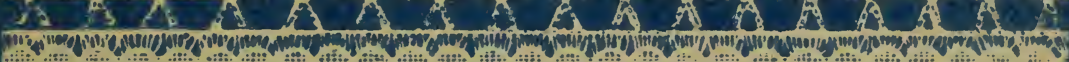

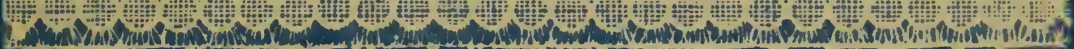

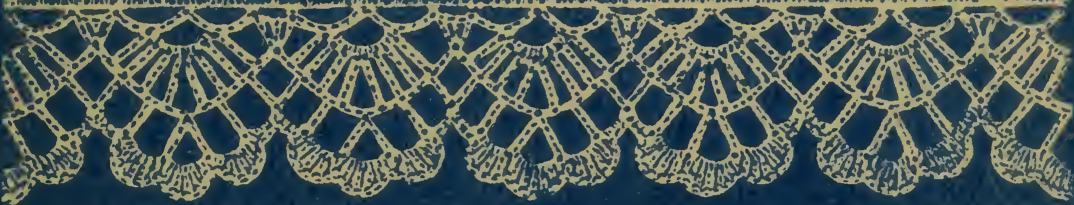

Hef

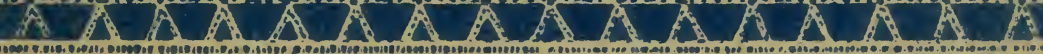

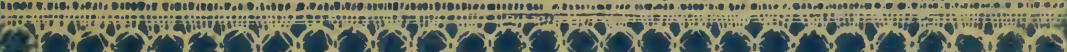

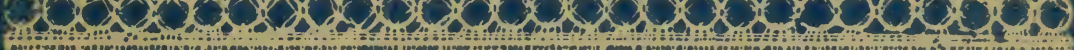
(5) 


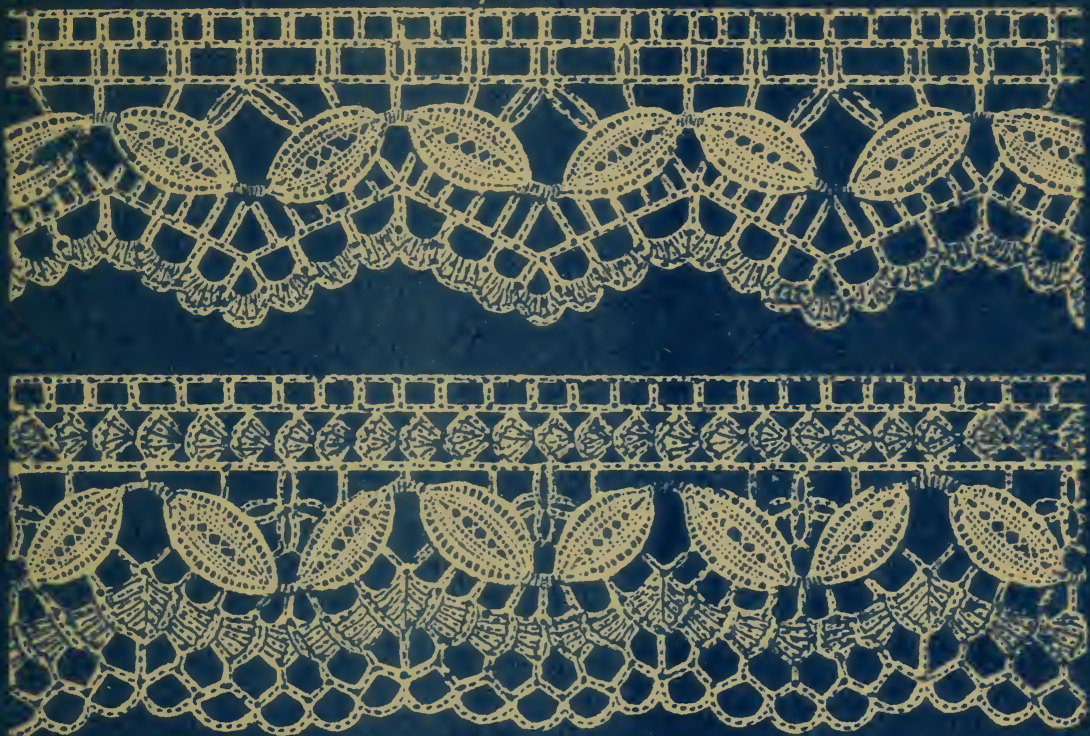

IfLW

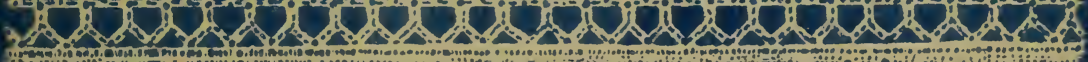

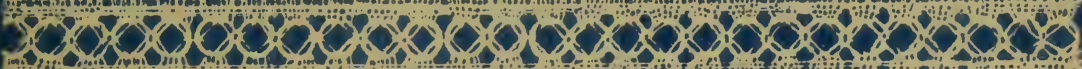
1.

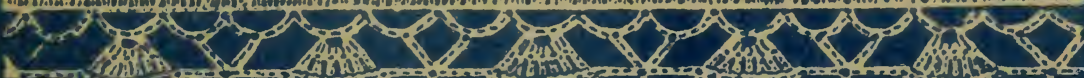
1.4. 1 (1)

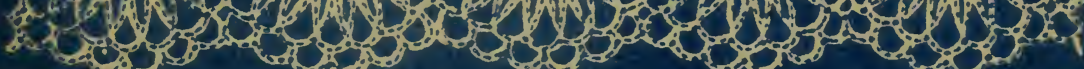

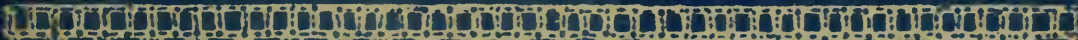

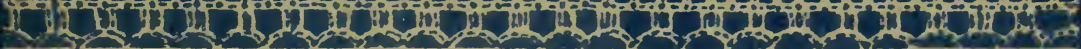

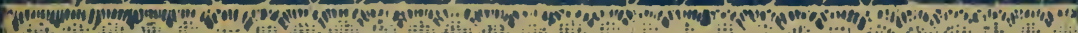

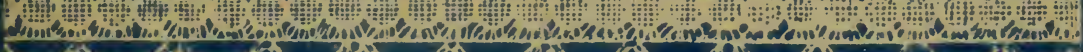

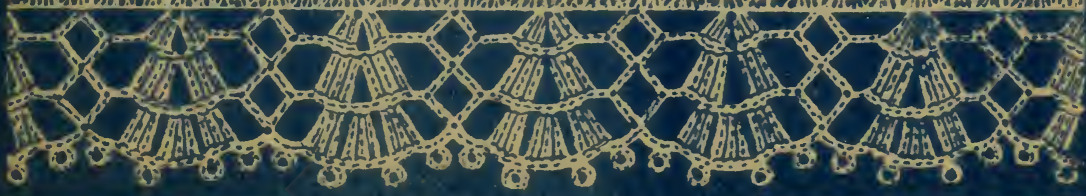





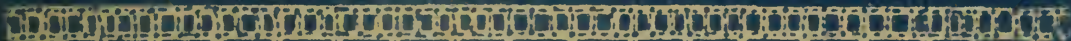
5.4.

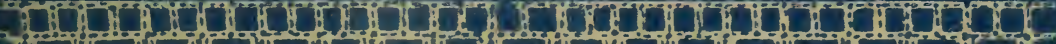
10

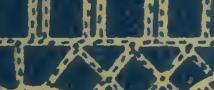

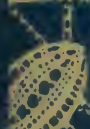<smiles>[C]1=C2C=CC1=C2</smiles>
o. 0 of

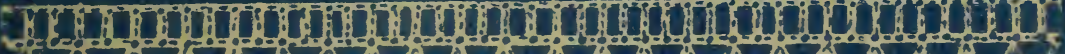

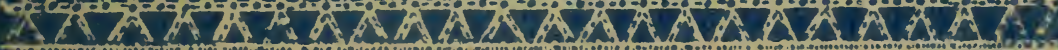

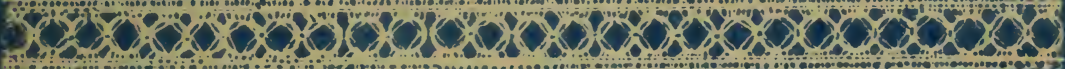

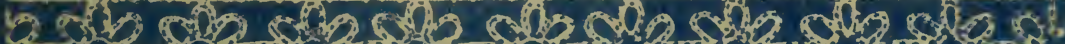

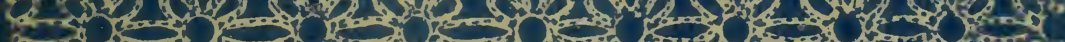
Q S.

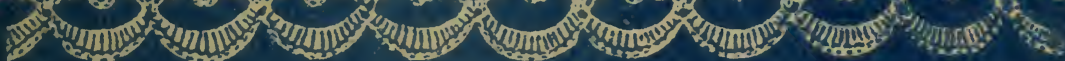

10

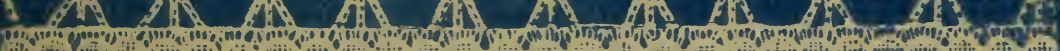
-

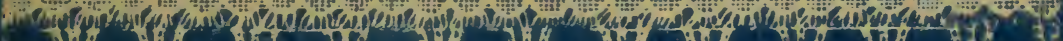

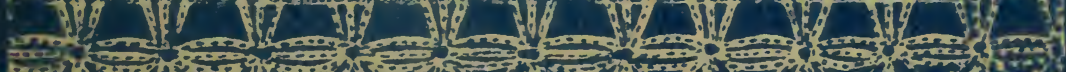

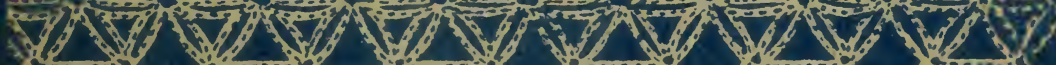
3. 3.

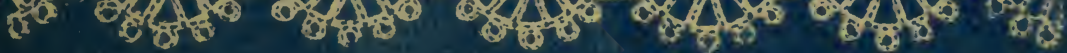





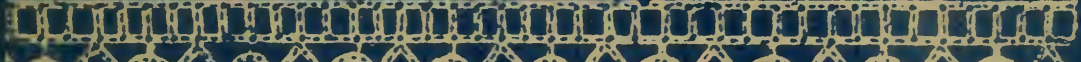

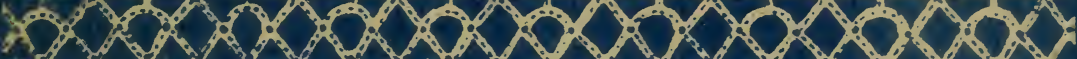

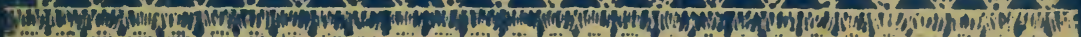
P.ti

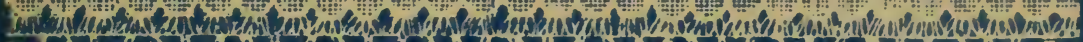
16 16.

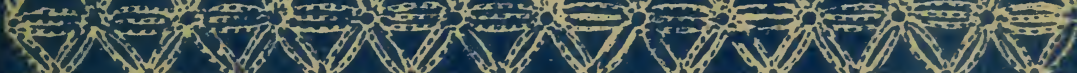

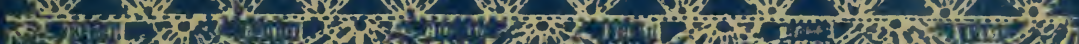

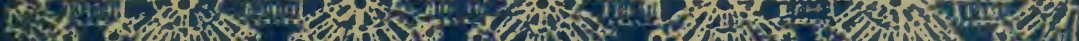

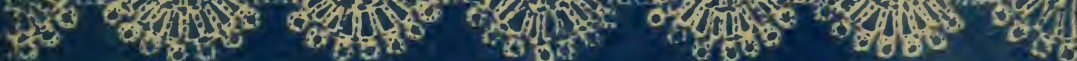

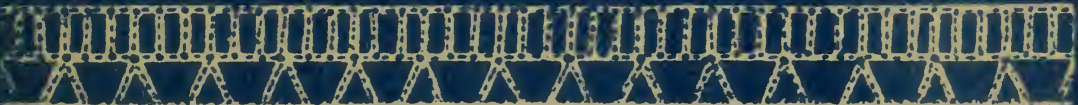
10.

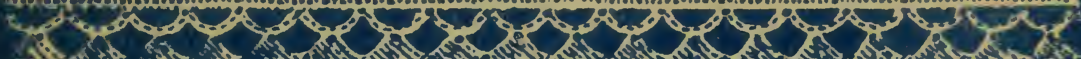

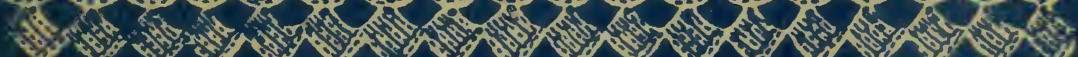

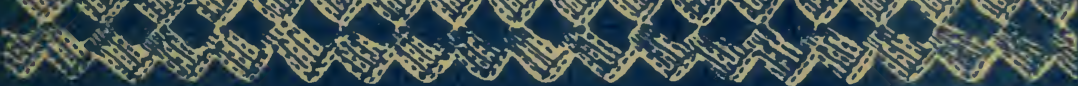

1.

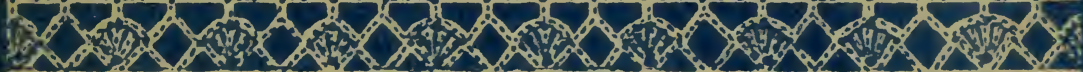

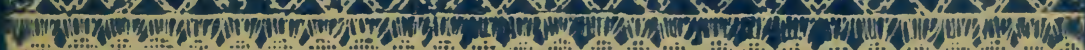

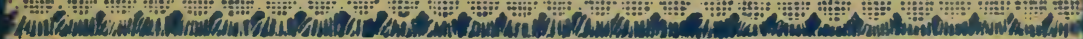

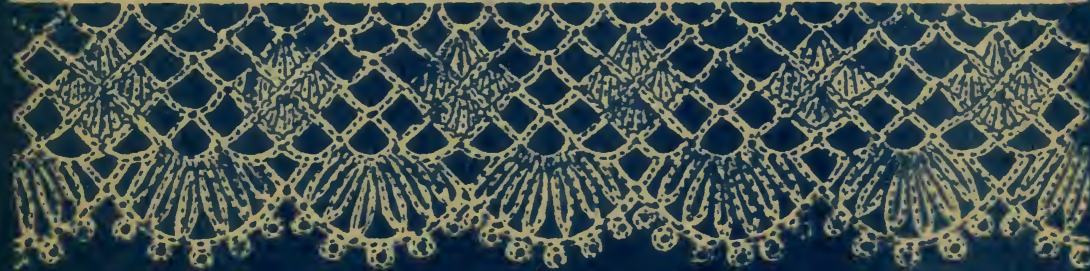




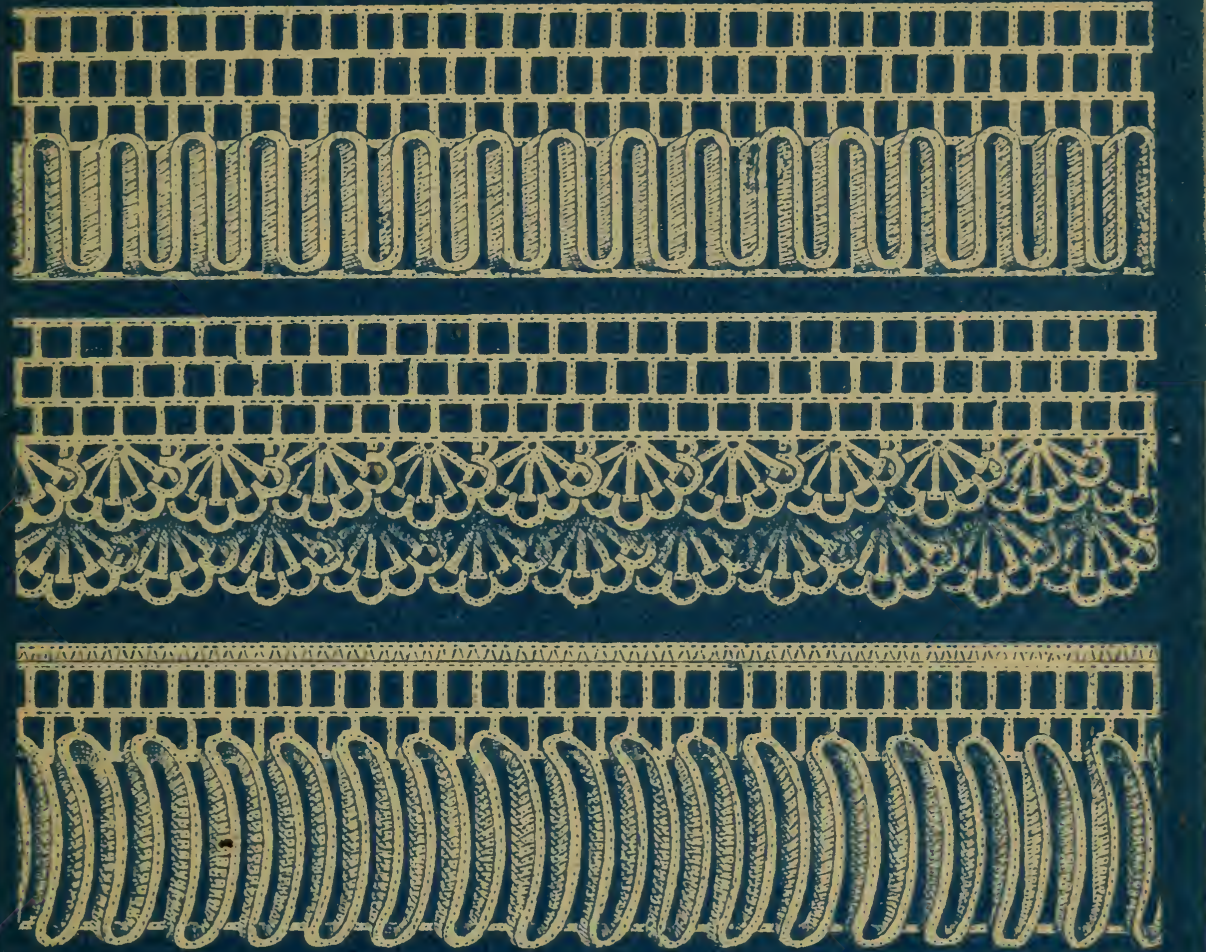

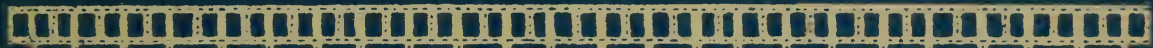

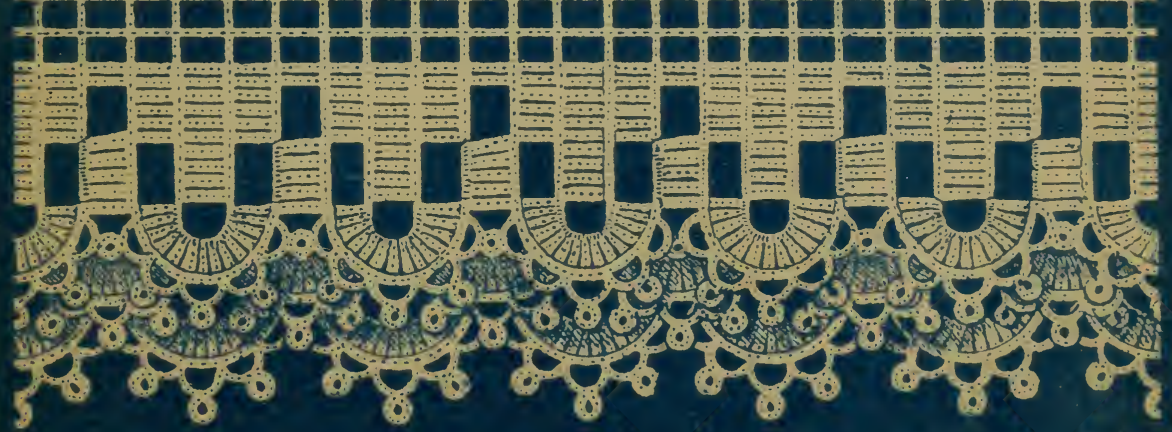

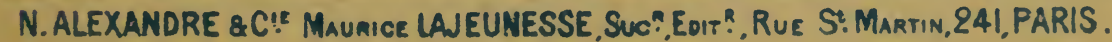





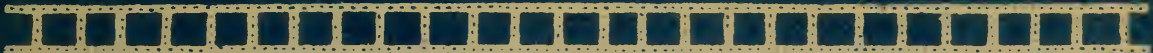

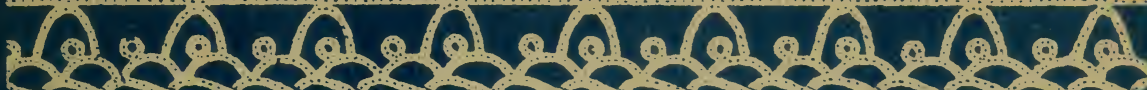

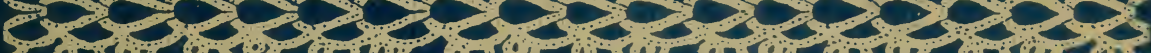

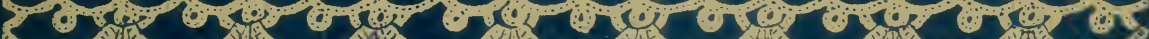

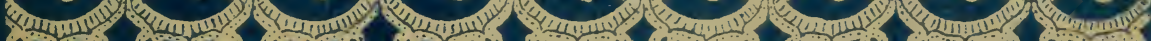

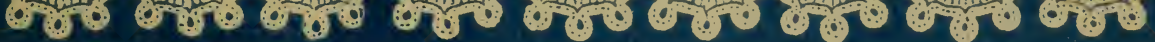
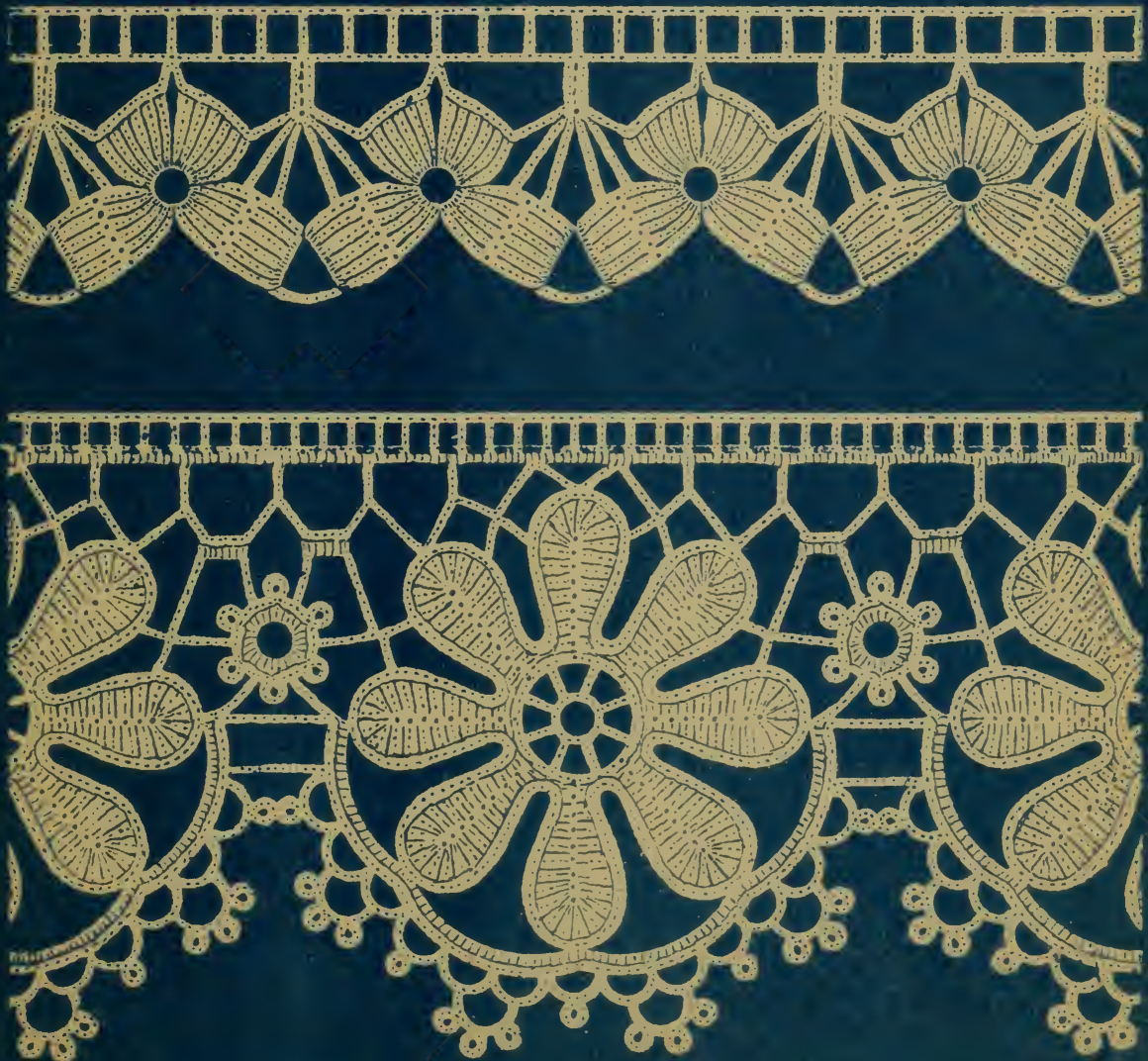



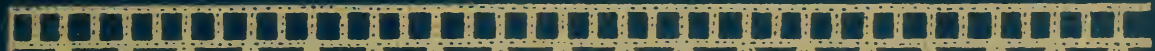

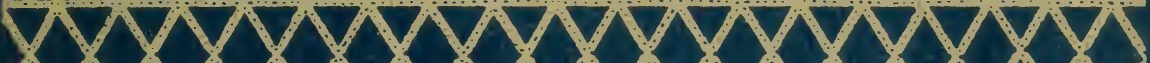
$\triangle \times \times \times \times \times \times \times \times \times \times$ MMXNAMVMNMNM

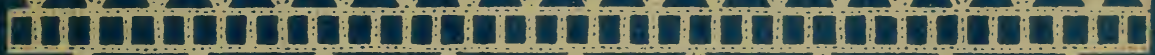

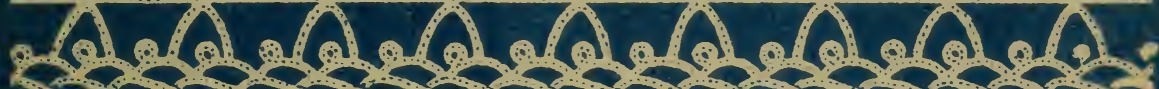

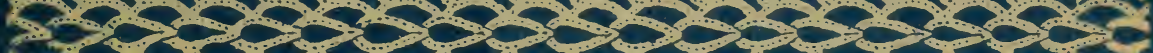

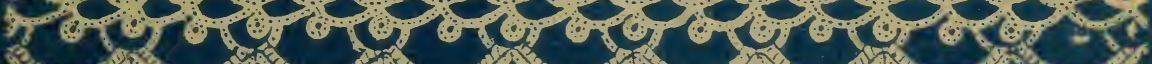

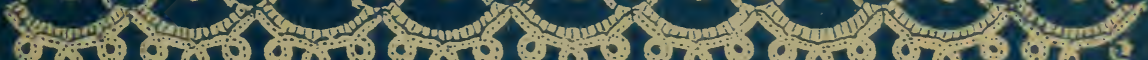

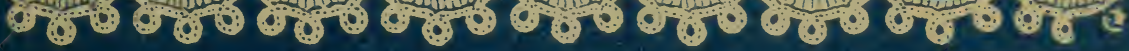

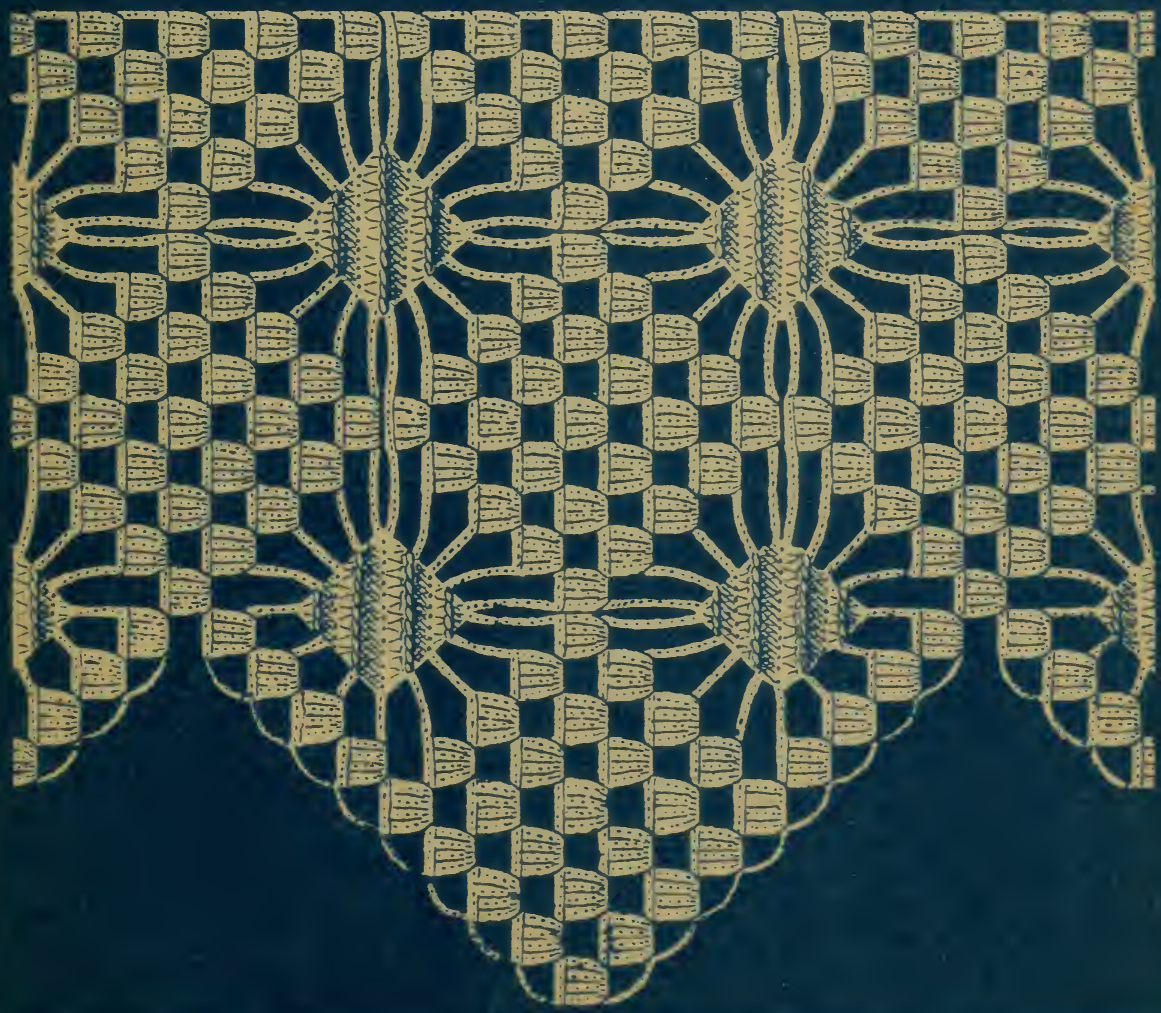




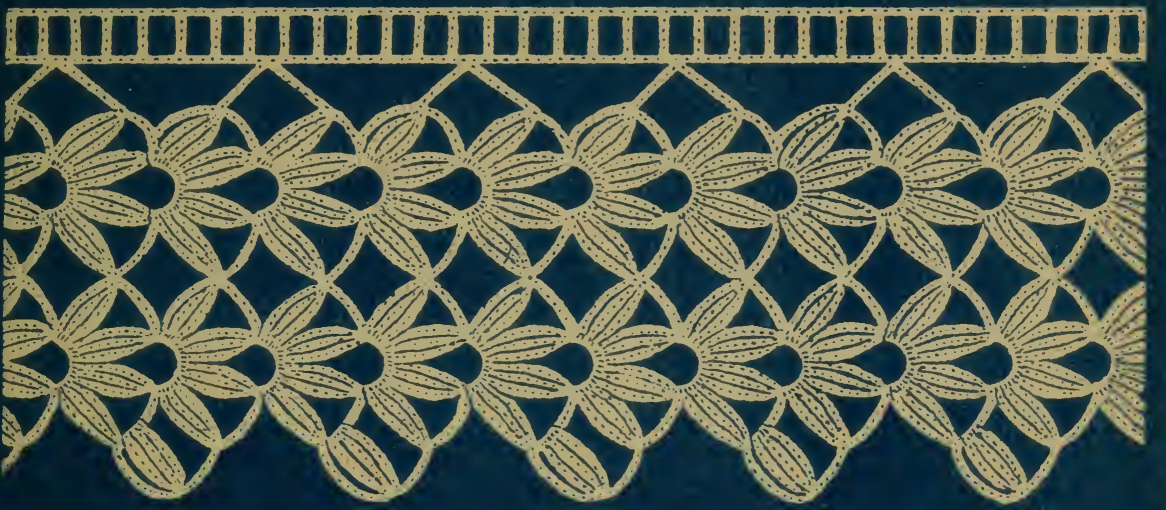

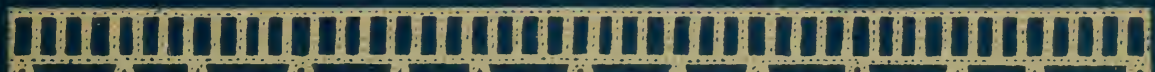
6

1000100000001

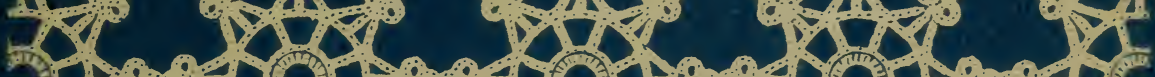

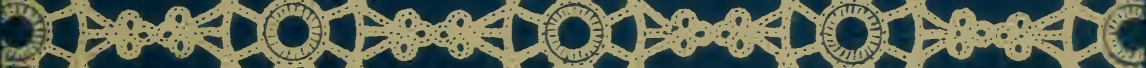

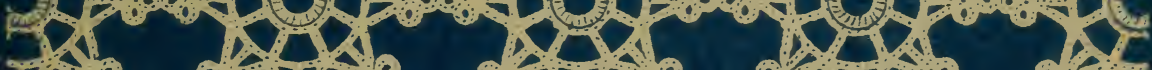

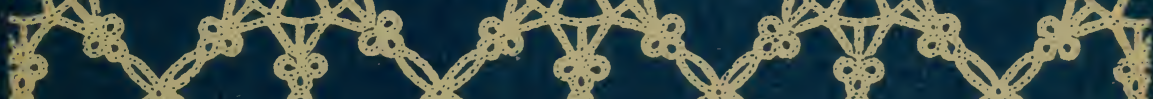

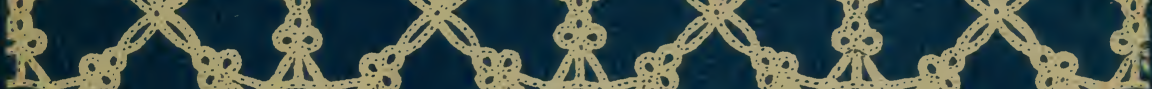

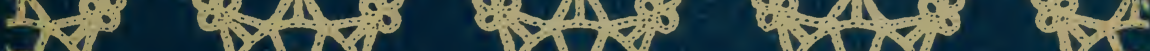
anj $1010+1$ 110101010101010

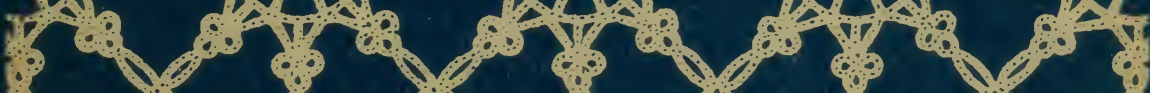
1001010

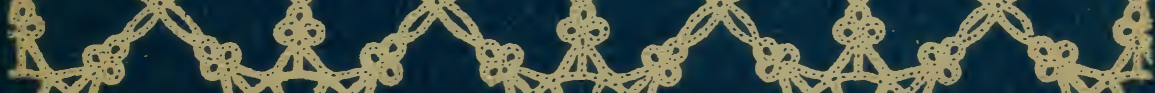

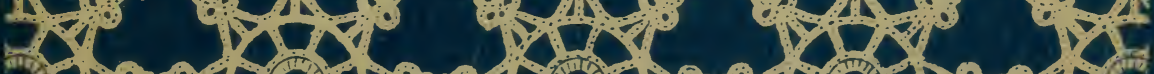

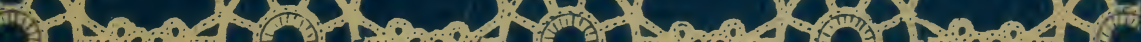

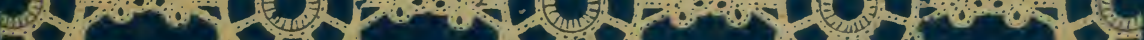

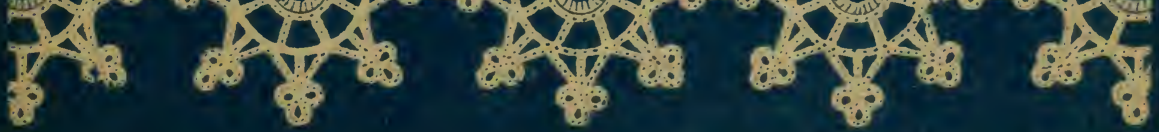





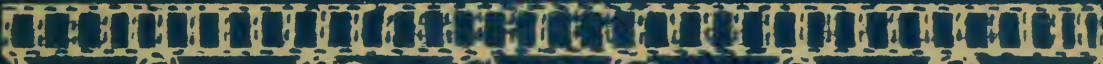

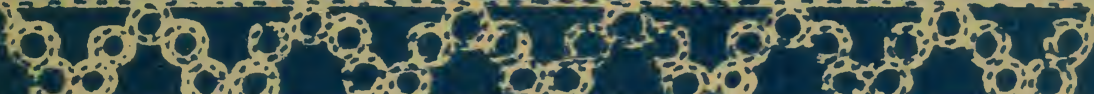

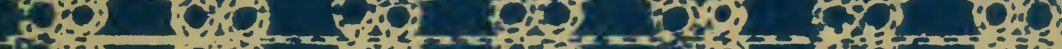
To 0 o 010

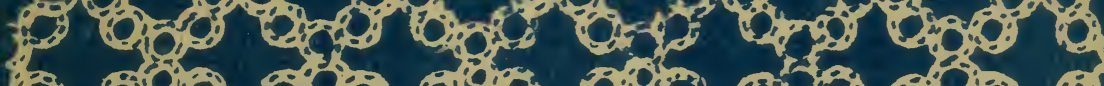

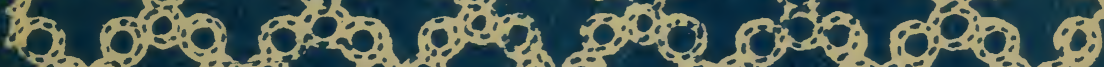

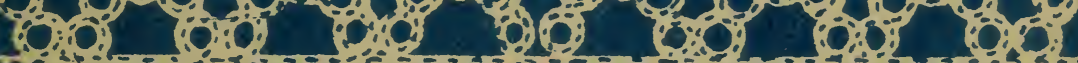
00 o 0 lo 000

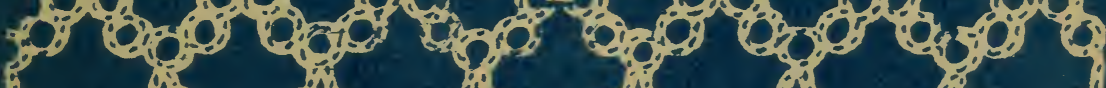

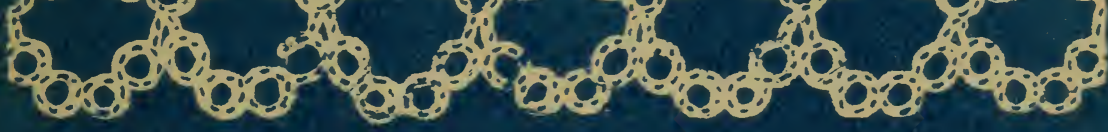

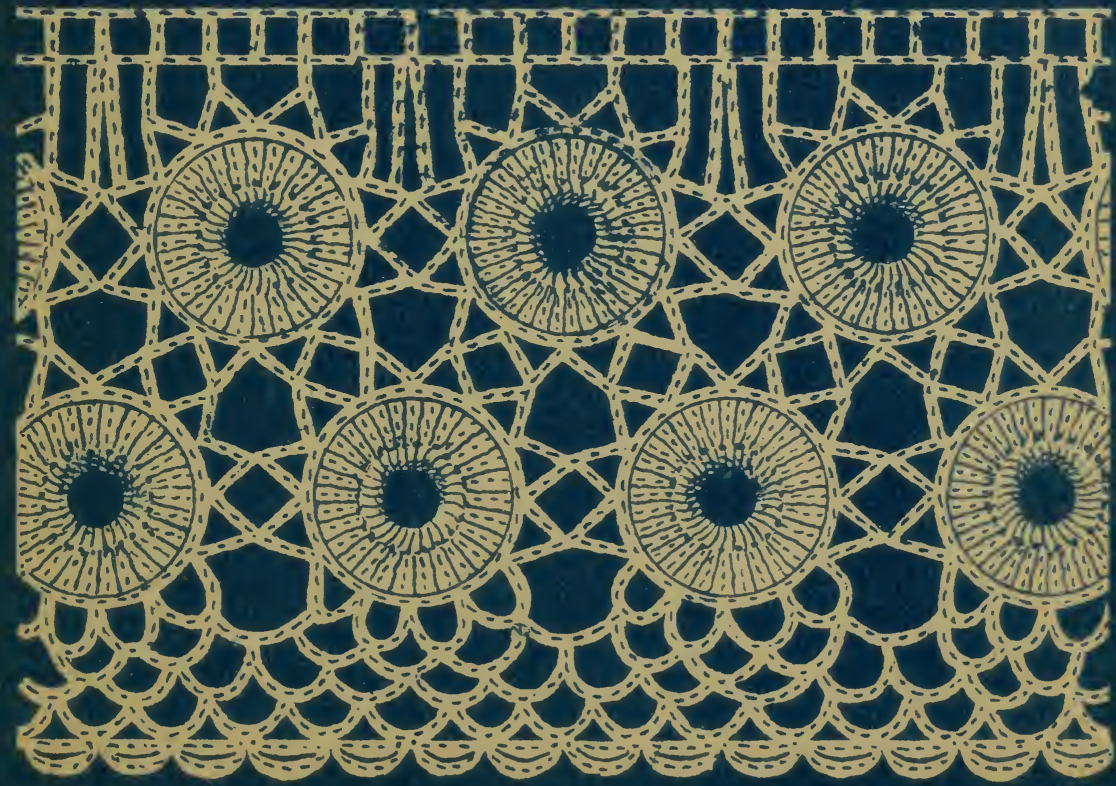





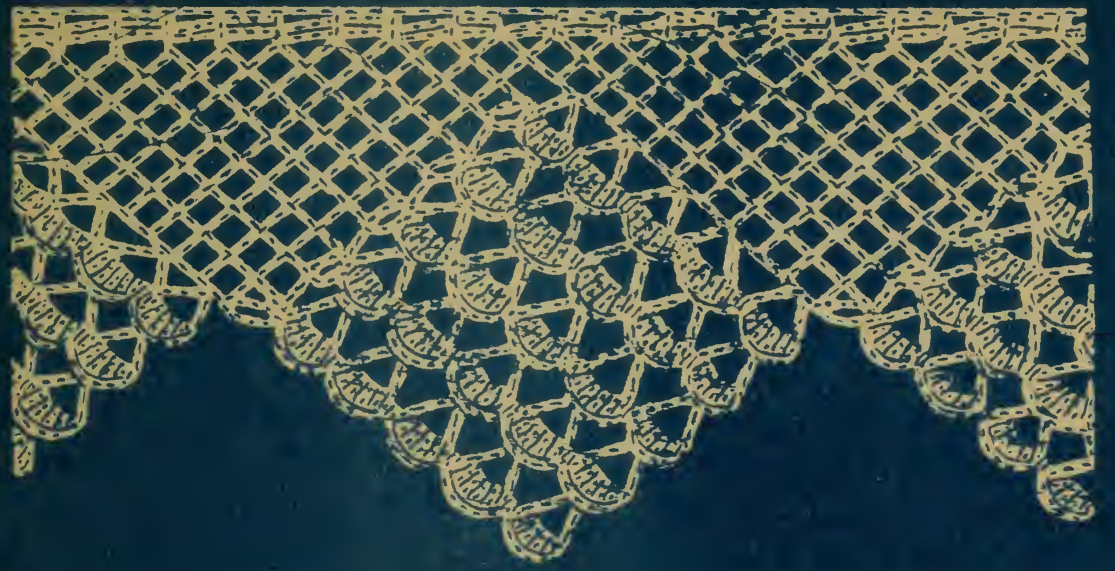

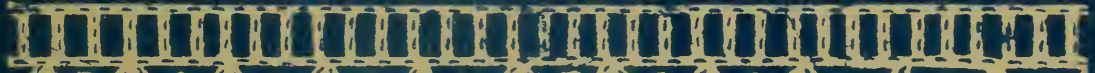

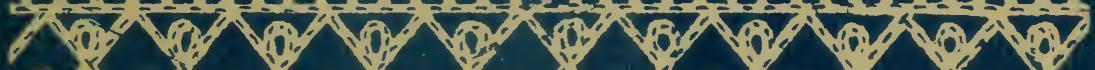

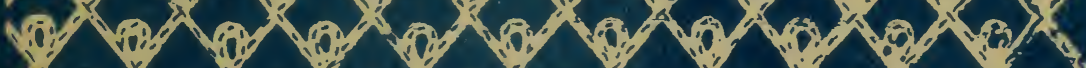
1) (1) (1) fol, (0.0) 



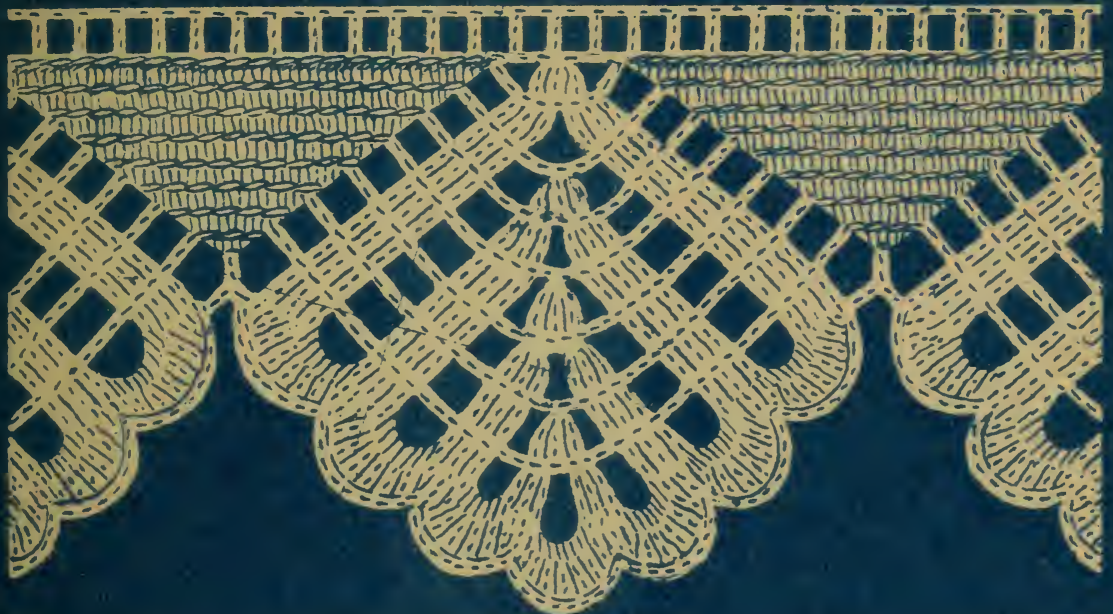

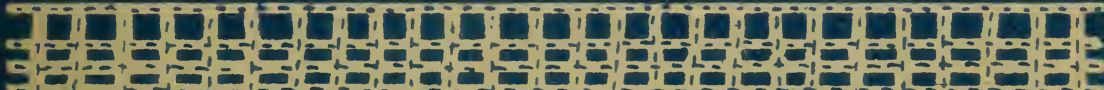
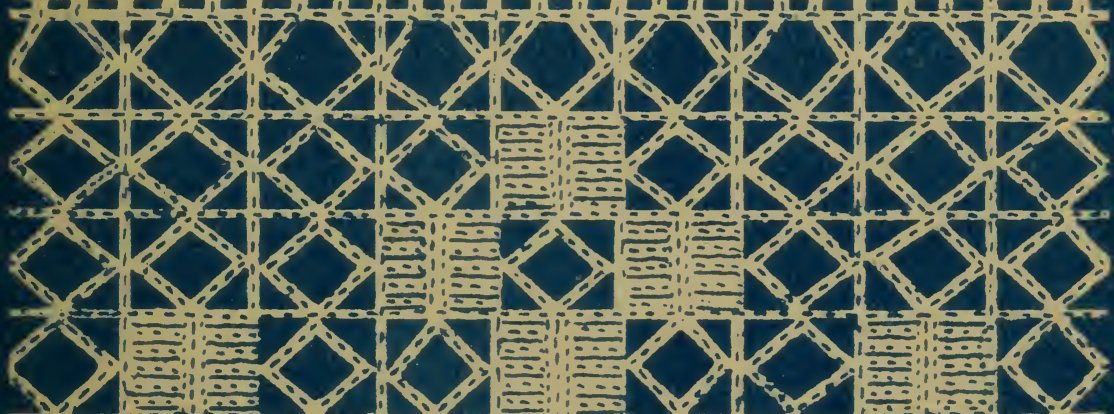

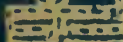

ind $y=0$

corrats

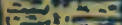

$100,10-2$
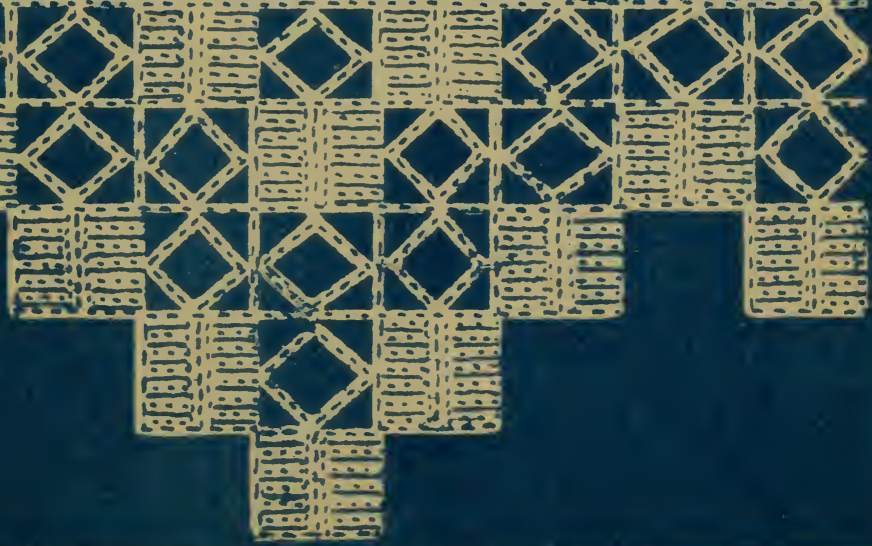

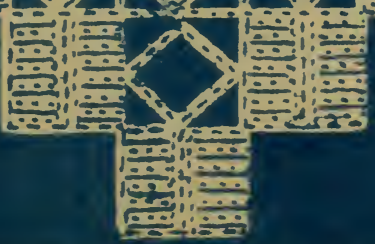





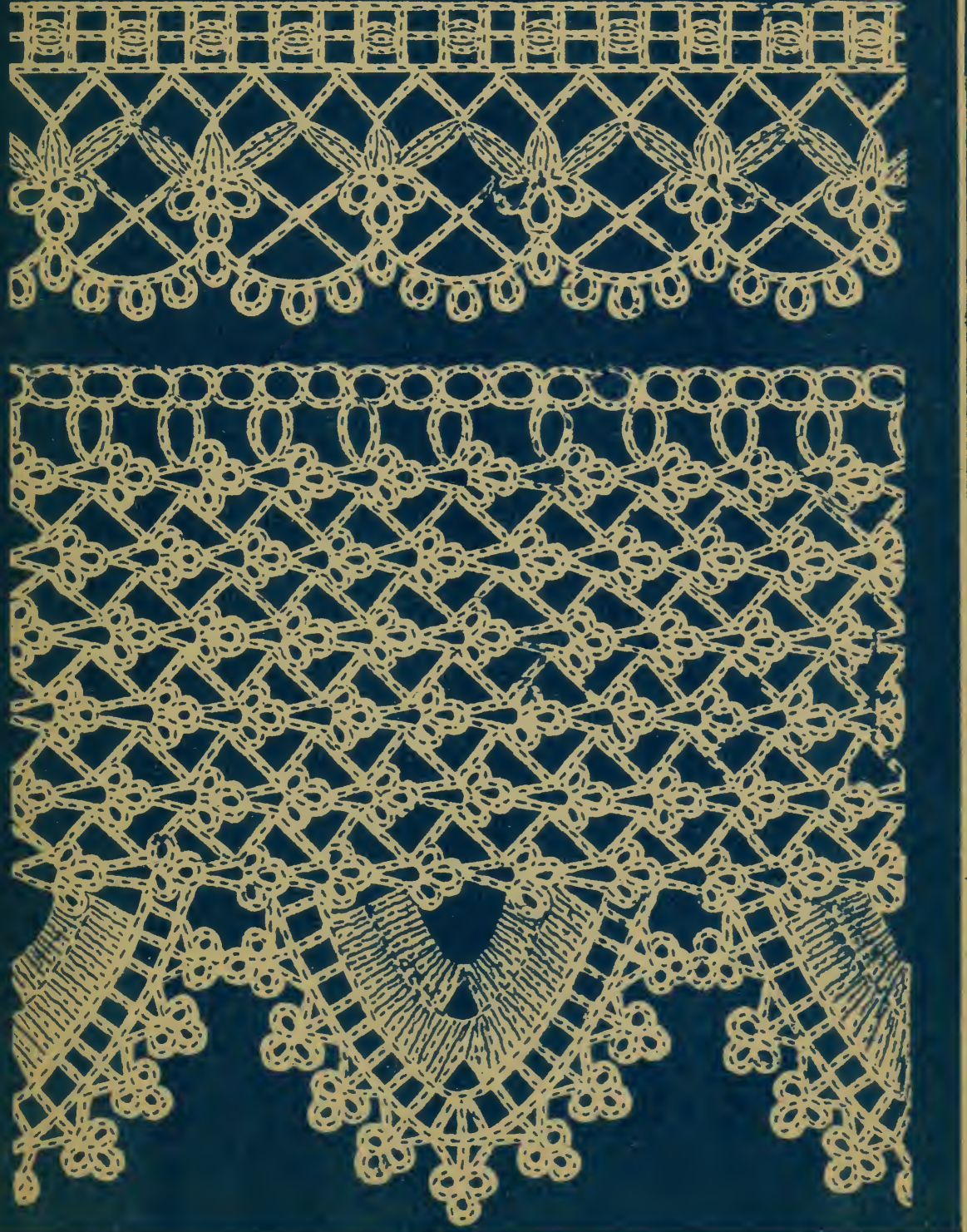





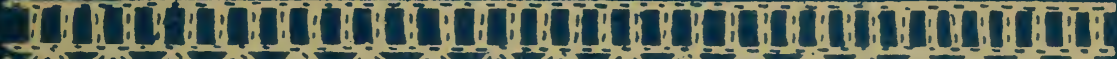

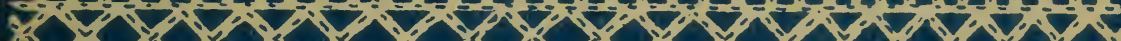
1. , i.

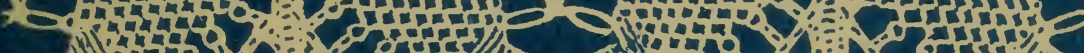

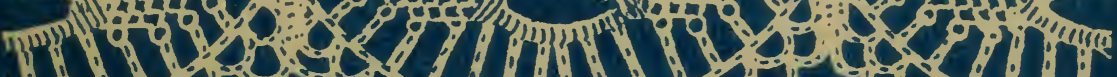
i)

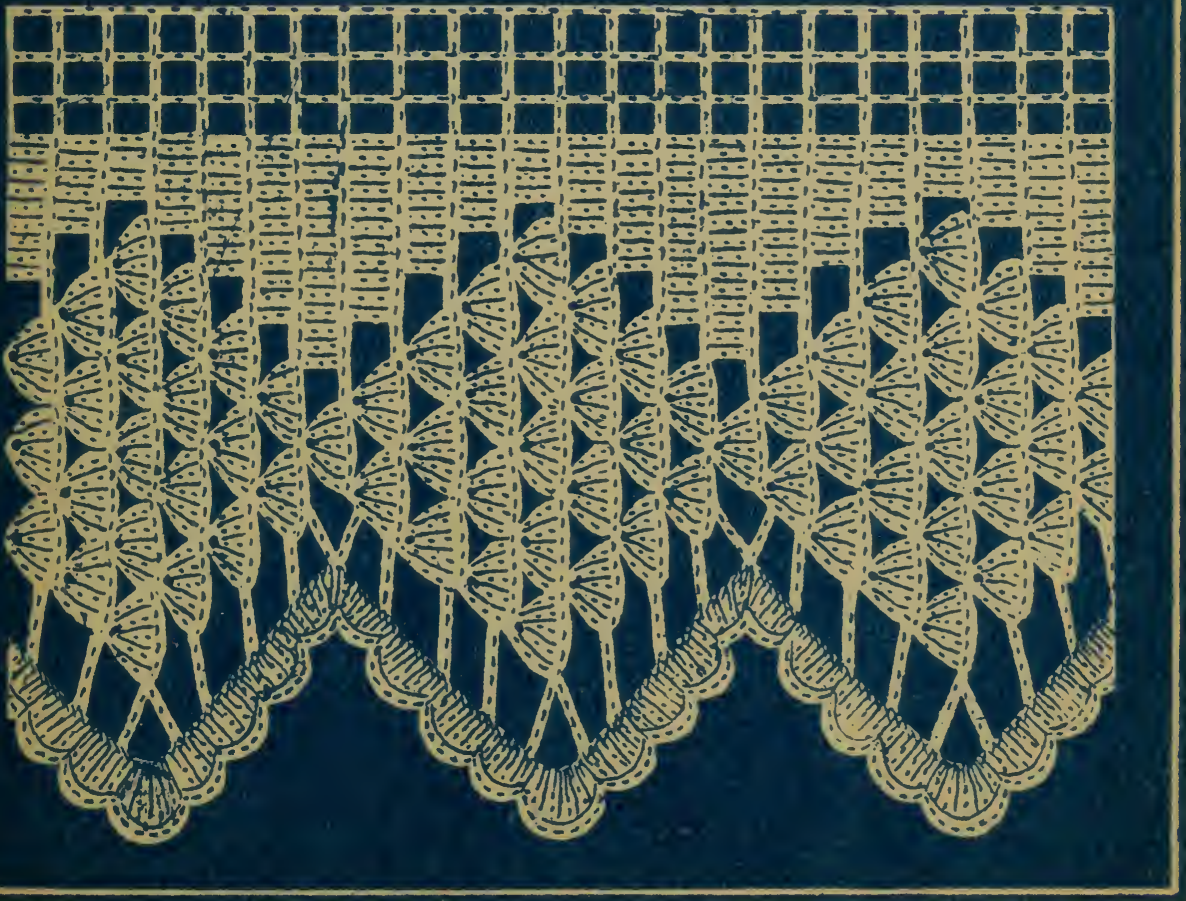

N. ALEXANDRE \&C! MAURICE LANEUNESSE, SUc?, EoIt?. Rue S! MARTIN, 24I, PARIS. 



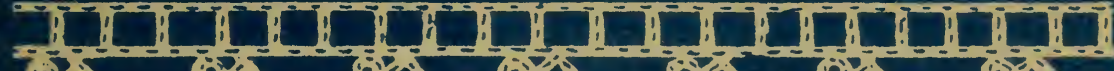

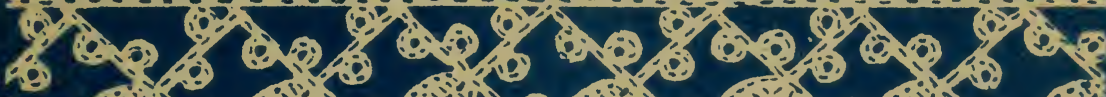
6) 燃

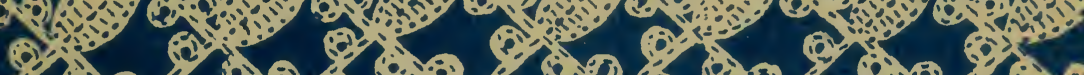

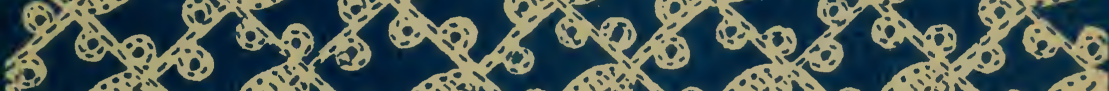
\%

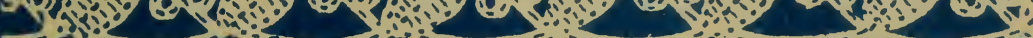

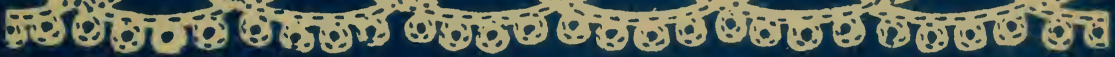

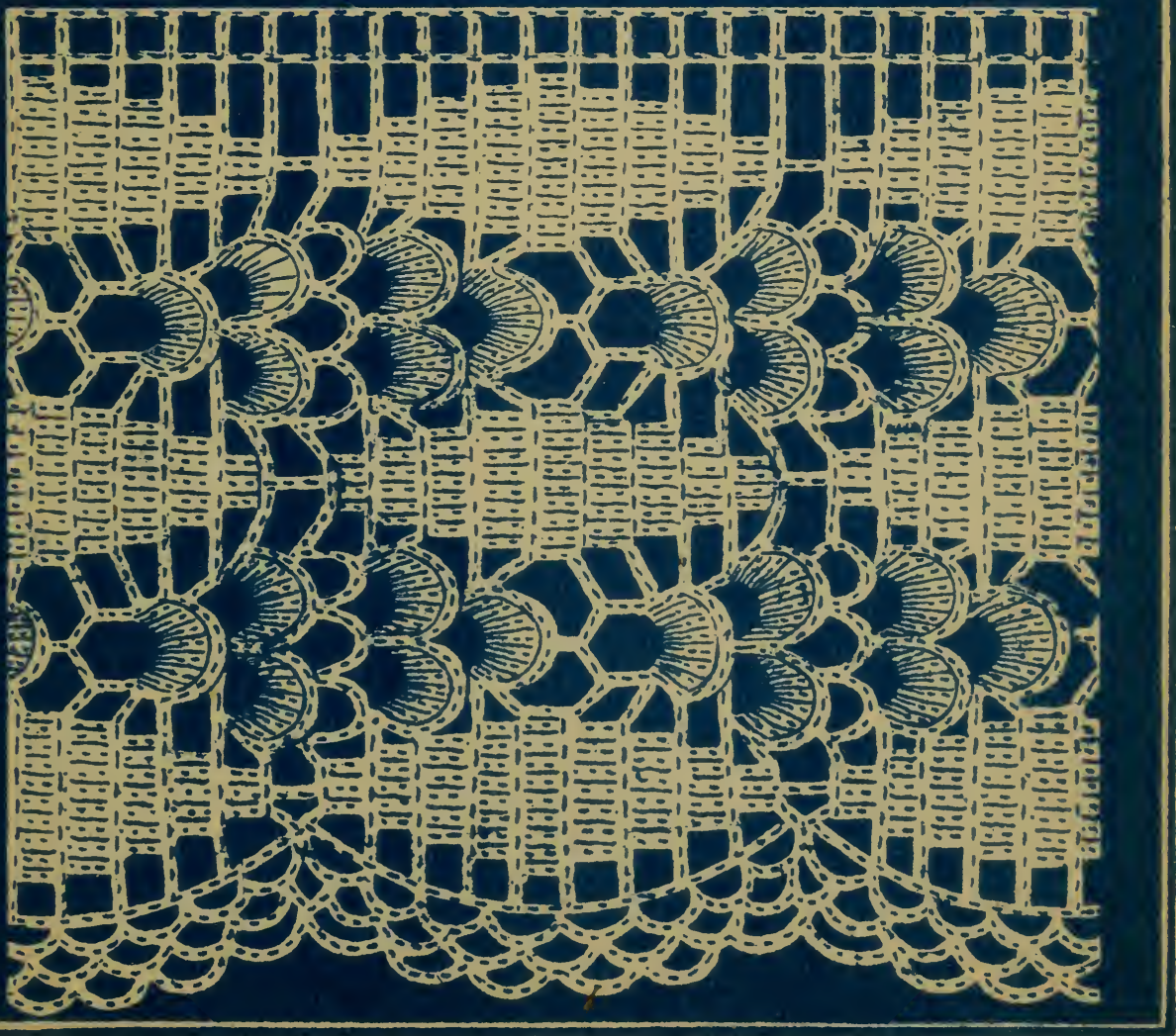




1, \% E a.

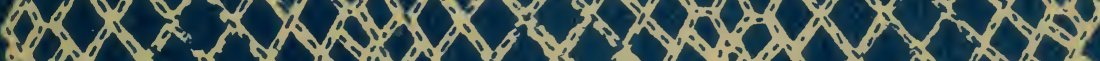
o d e. N

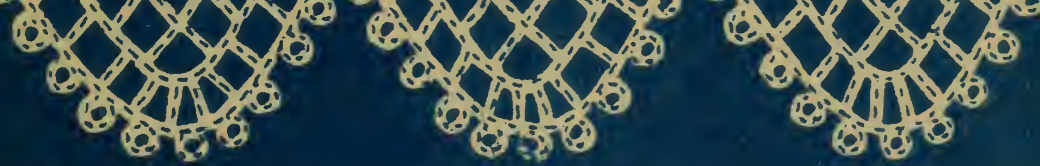

15,

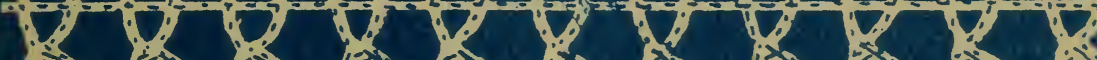

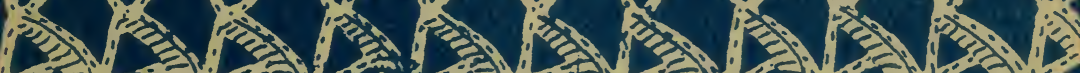

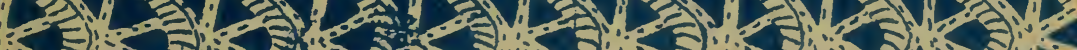

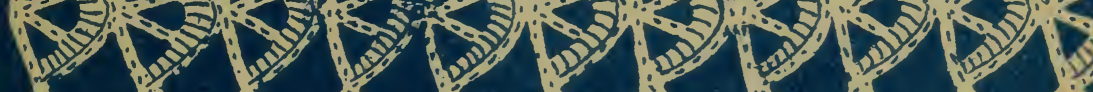
I 10 is

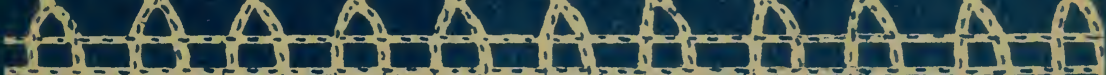

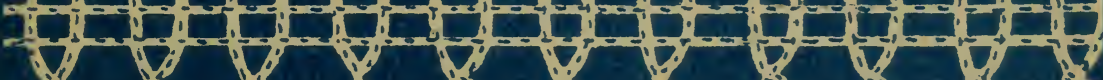
;

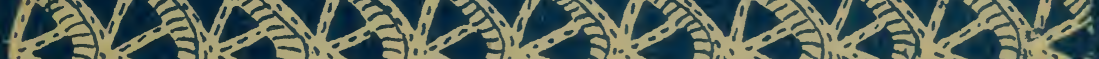

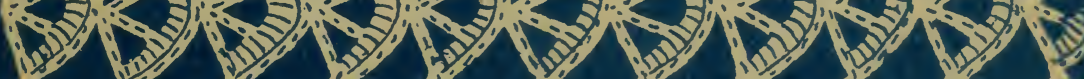
(1)...

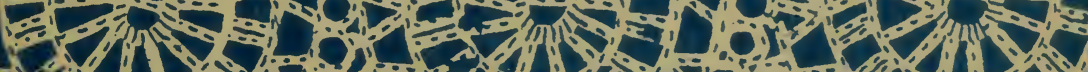

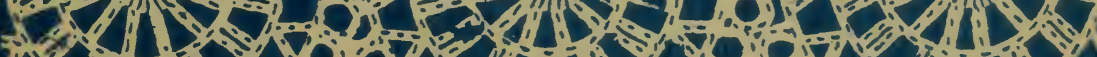
1) ili ll, Q 



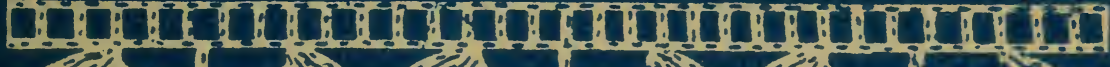
(1)

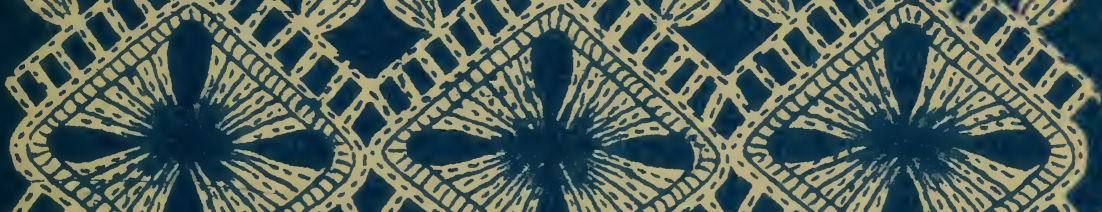
-1.0. in:? (2) is, (4)

and S1 

PO

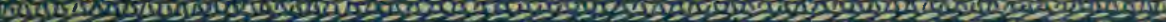

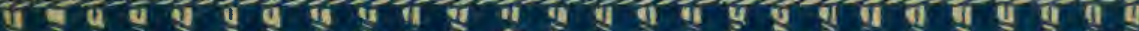

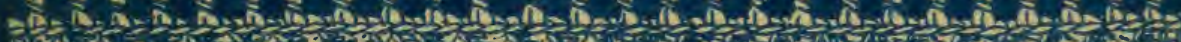

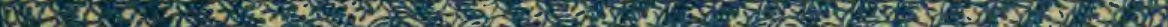

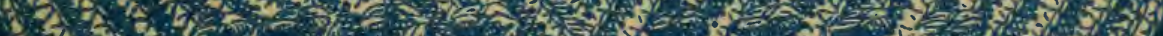

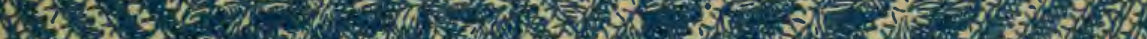
15.

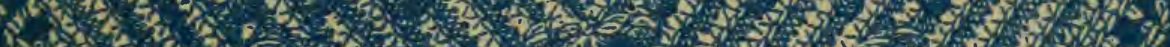

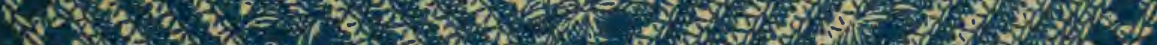

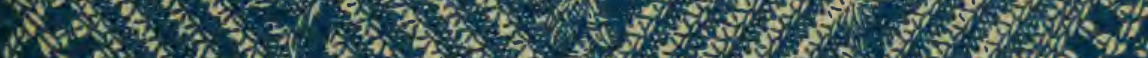

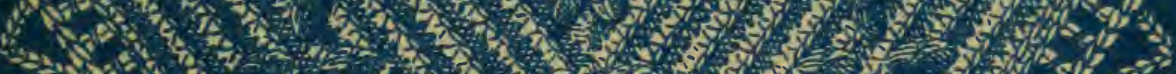

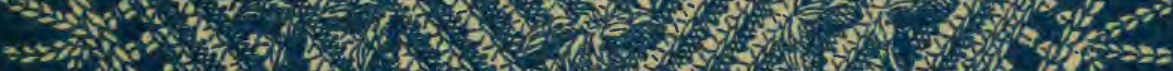
2.

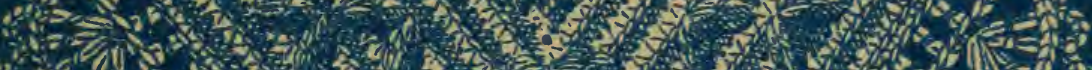

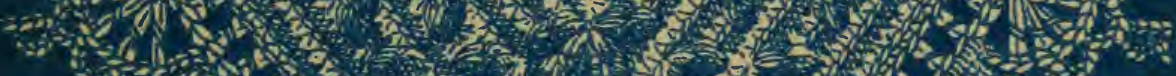
-

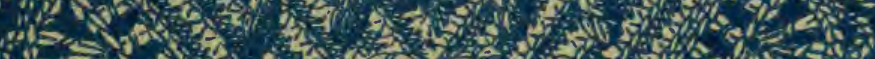

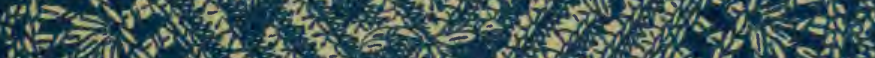

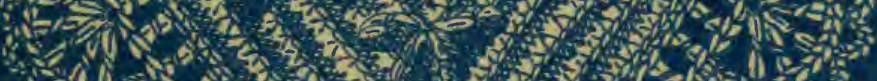
2.

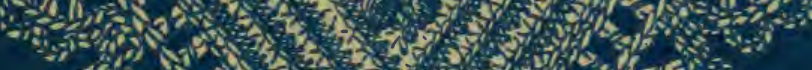

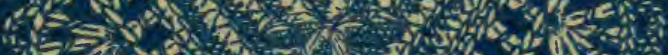
if 4. 19 . Hit

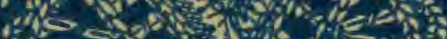
*

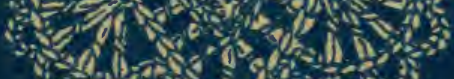

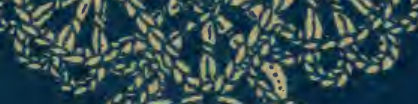

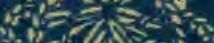
1.'

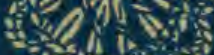
- 



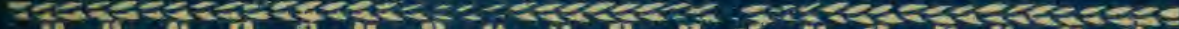

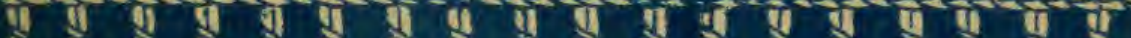

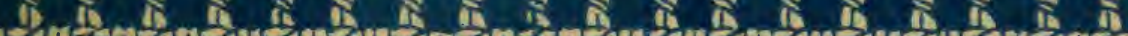
1)

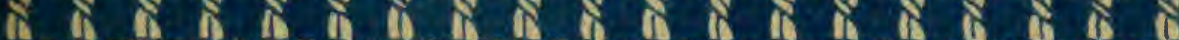

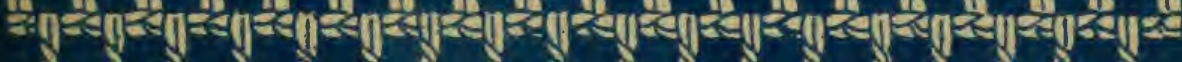

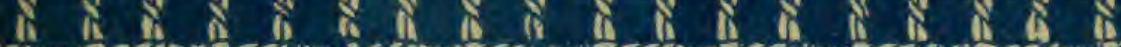

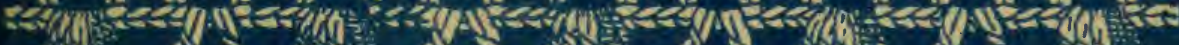

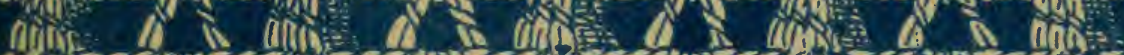

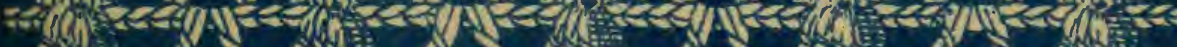

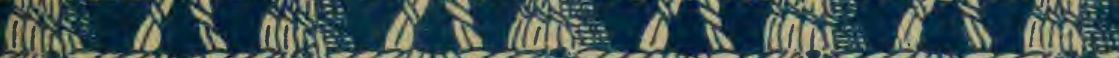

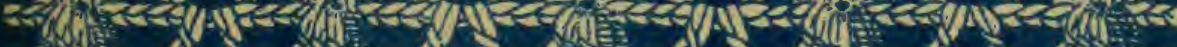

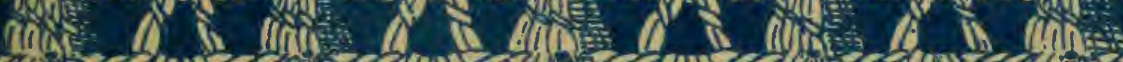

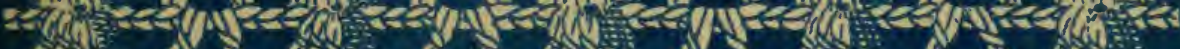

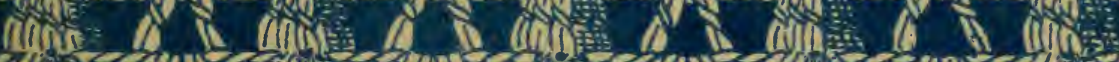

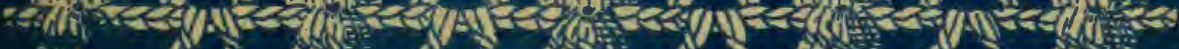

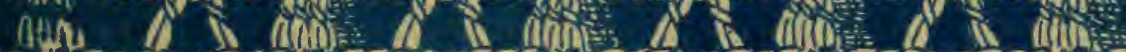

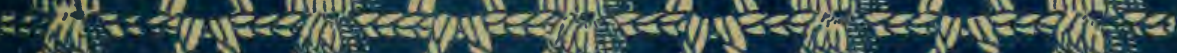

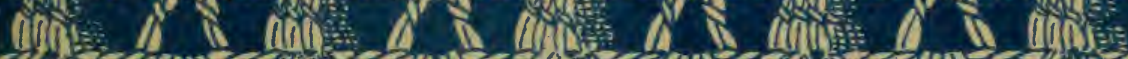

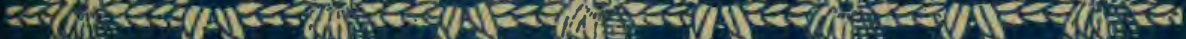

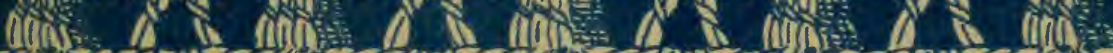

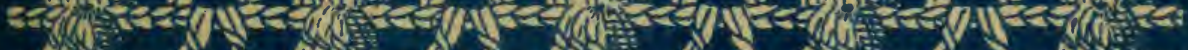

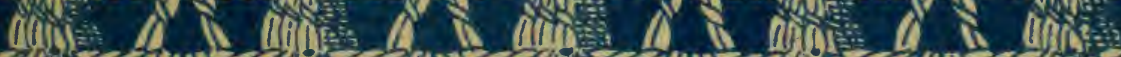

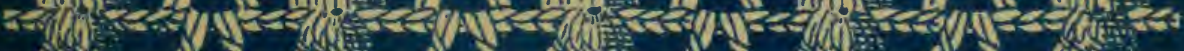

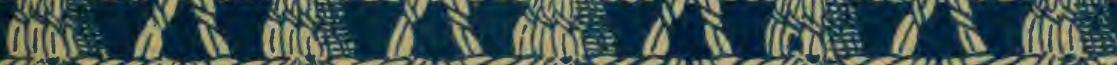
Eas

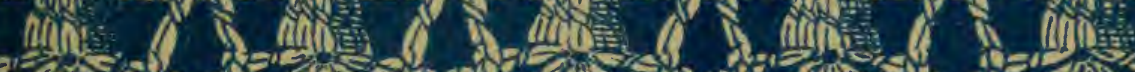

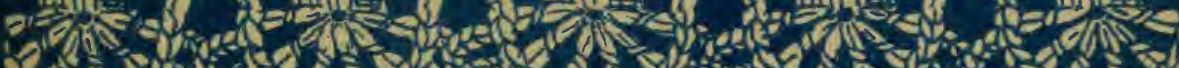
Nete (1) (2) 200 2. 898 Q.

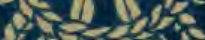
28 क क स or.es: are 2 -

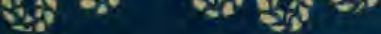
80 क

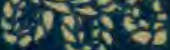





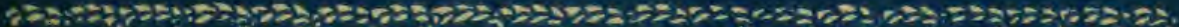
an $n$, n

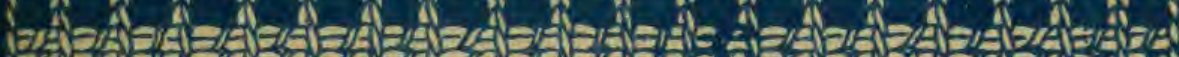

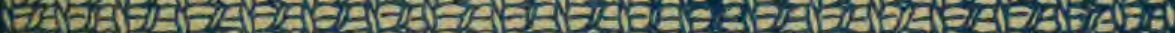
IPA

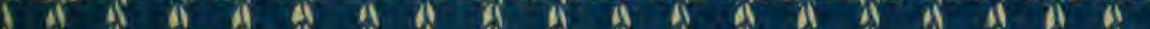

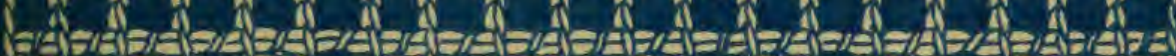

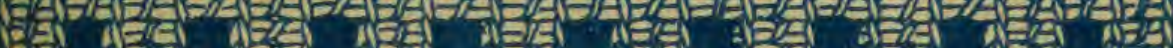

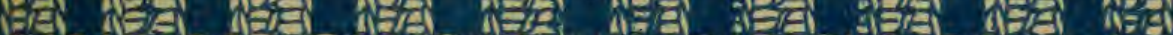

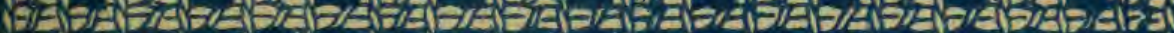

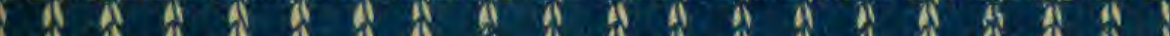

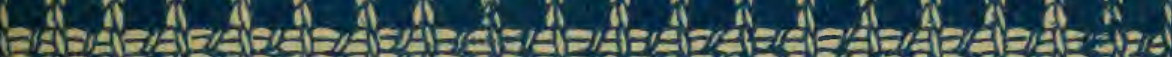

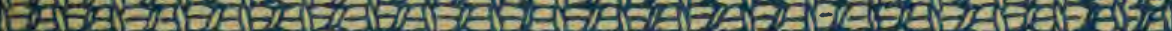

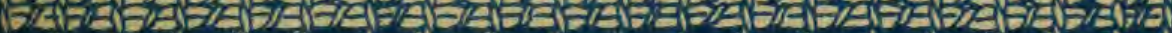

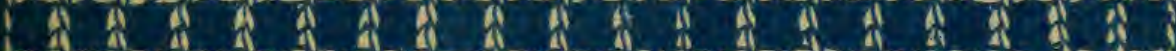
ip 184, L26. $y=3$.

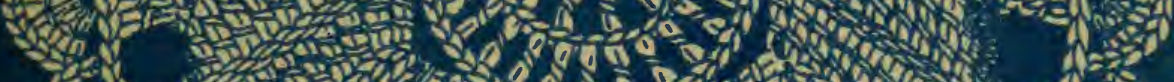
1.

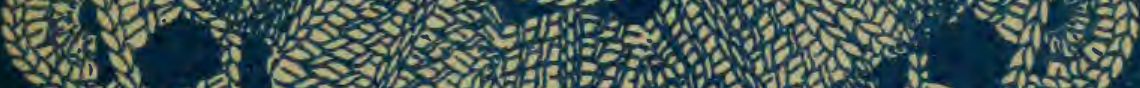

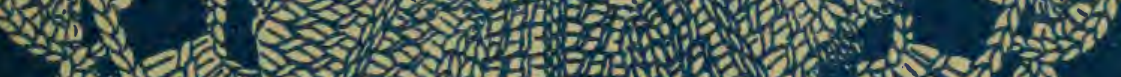

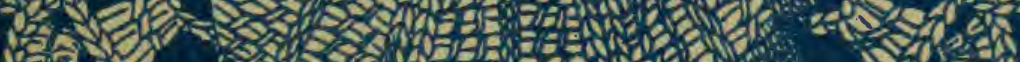

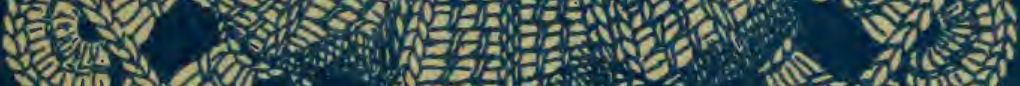

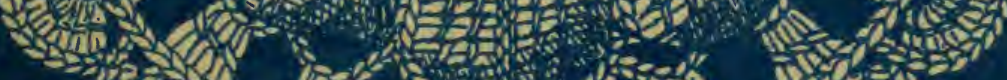

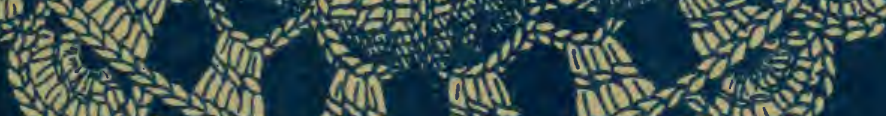

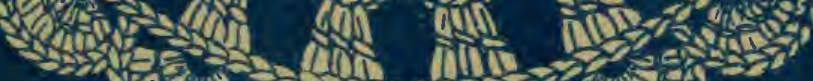

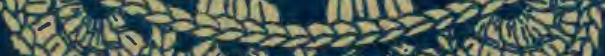

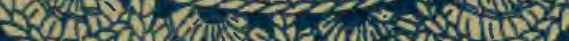

20 . 

: $=\frac{3}{2}$ पे

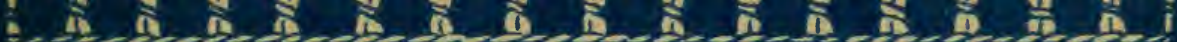

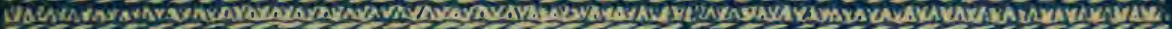

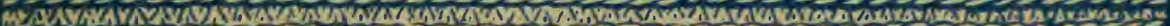

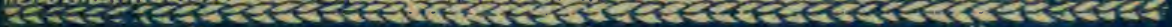

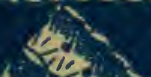

dis Sol

(c)

S.

s.

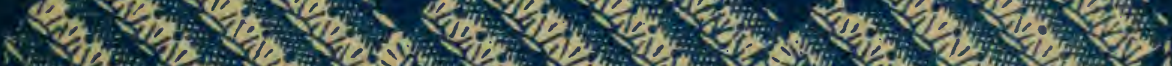

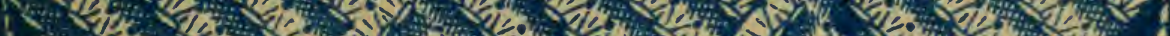

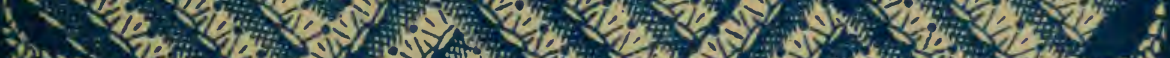

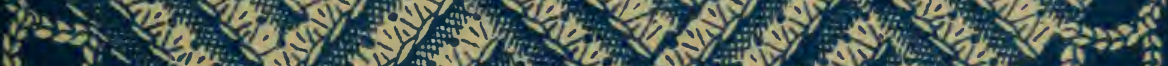
1) 1 is

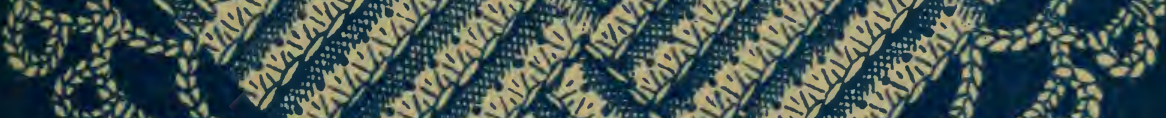

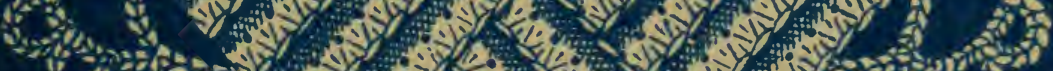

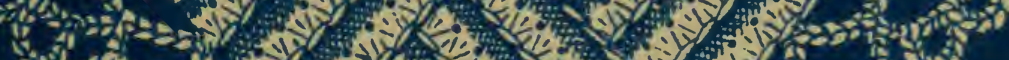

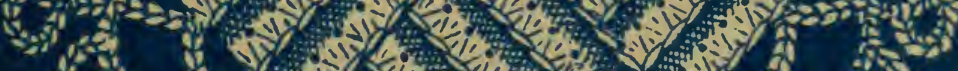

$$
\text { 1. }
$$






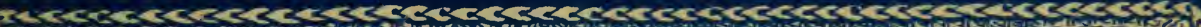



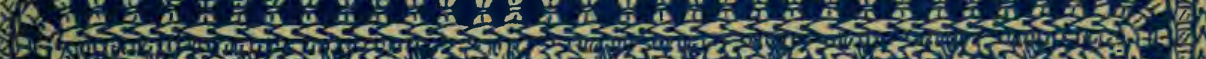

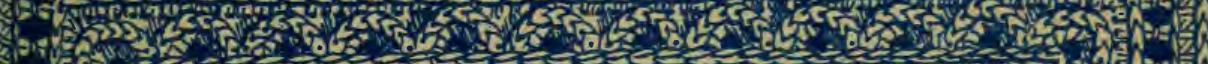

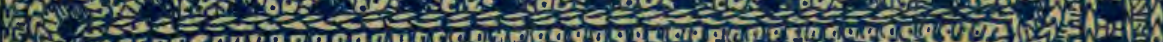

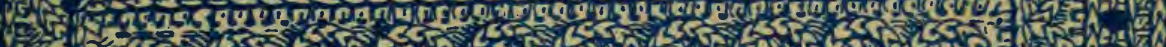

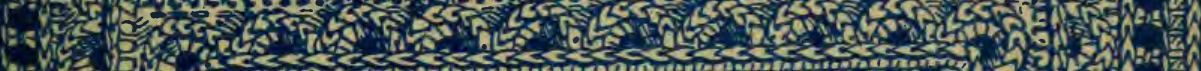

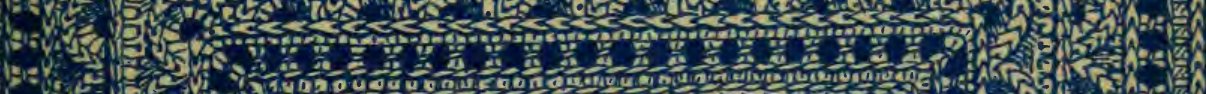

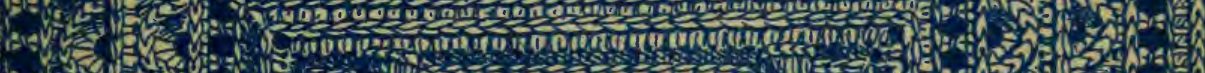

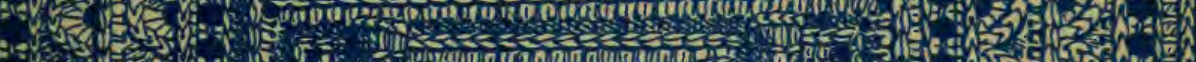

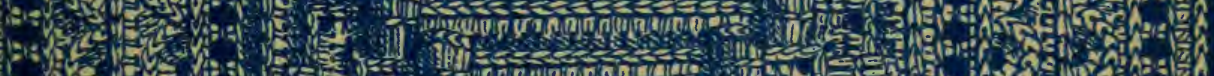

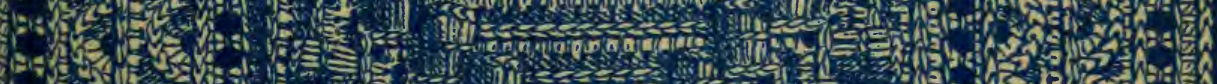

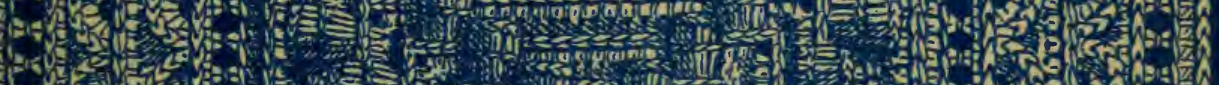

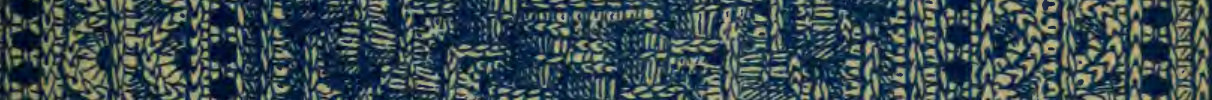

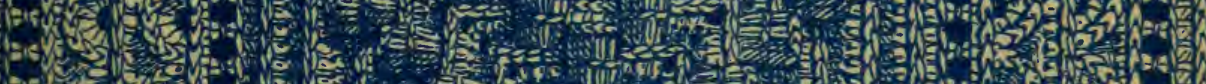
(a)

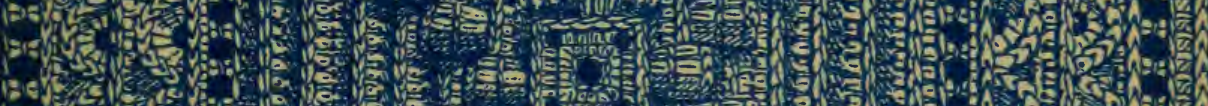

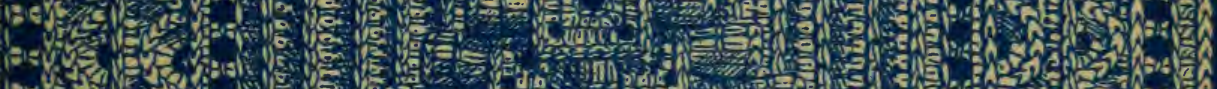

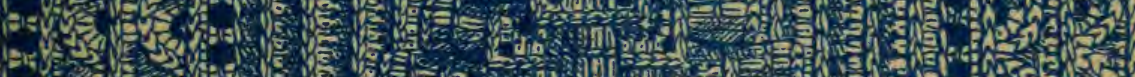
SeV

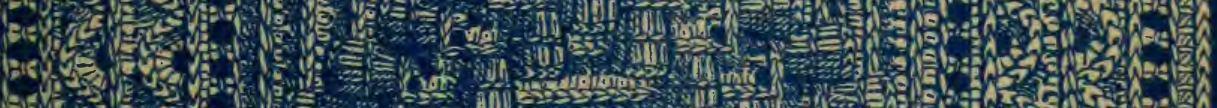

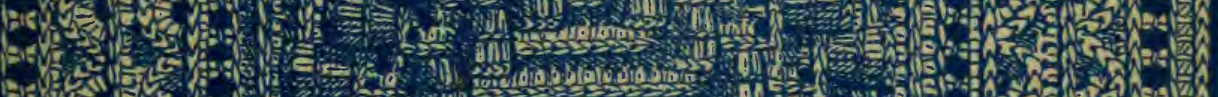

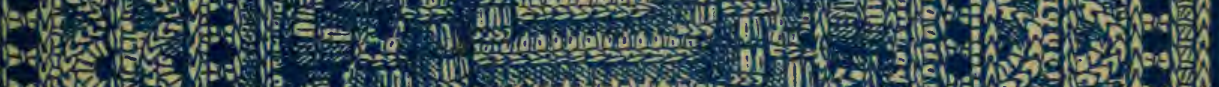

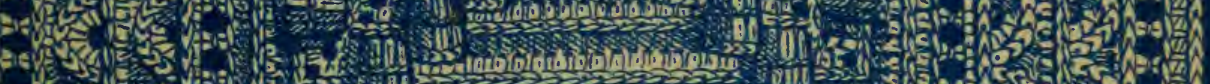

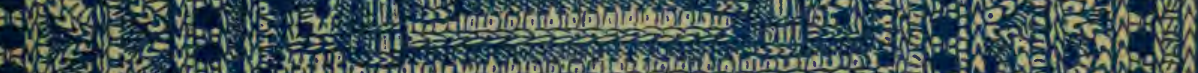

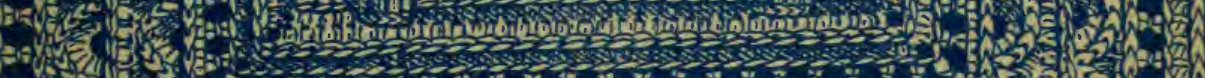

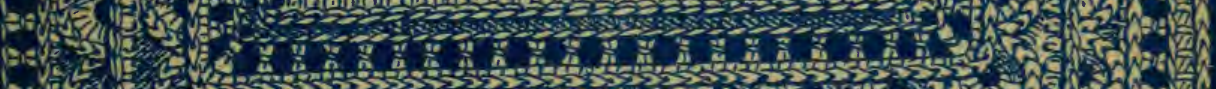

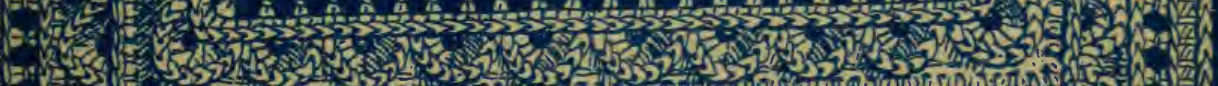

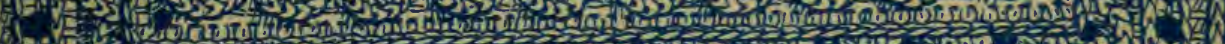

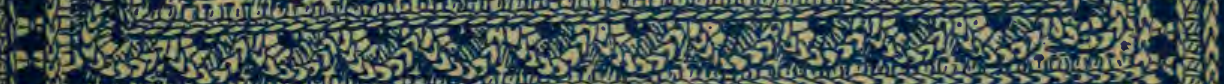

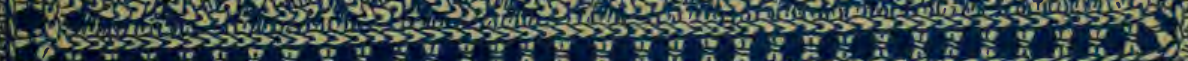

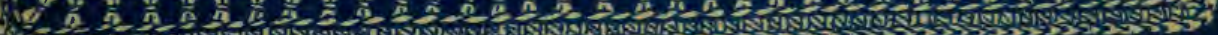





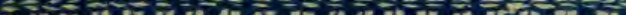

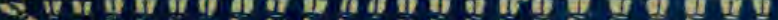
10:3

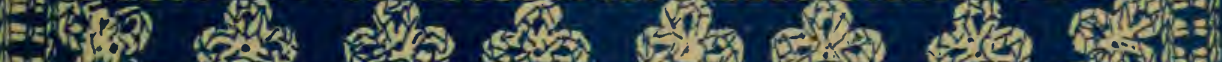

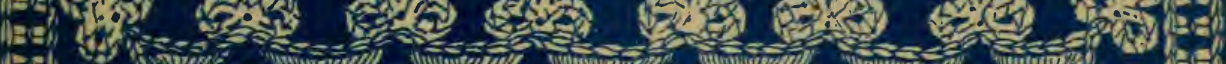

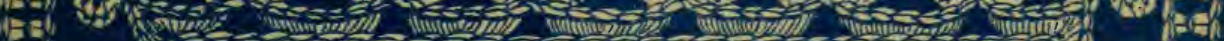

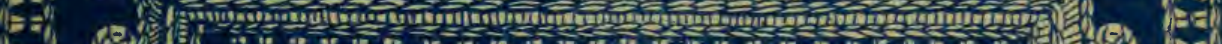

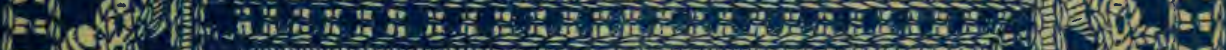

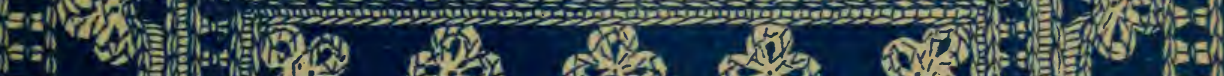
(B)

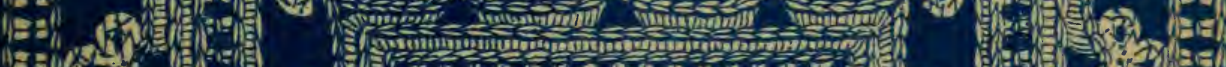

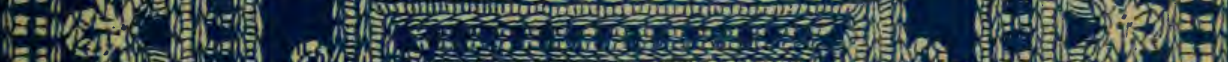

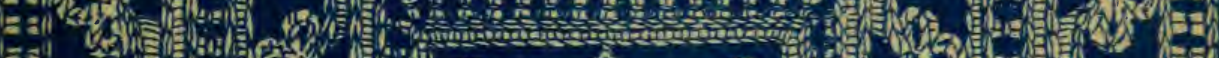

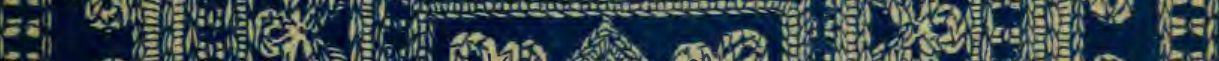

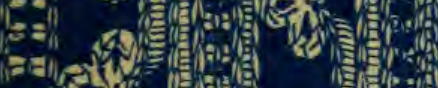
Es a CEA Cy Ea

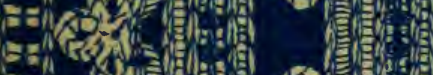

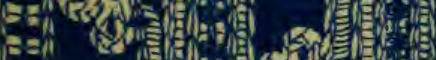

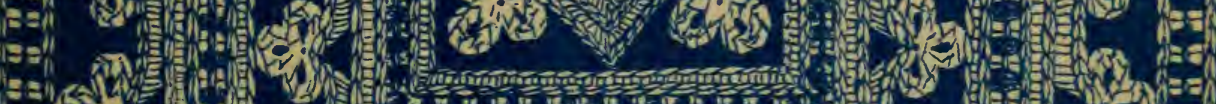

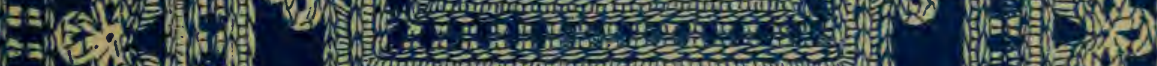

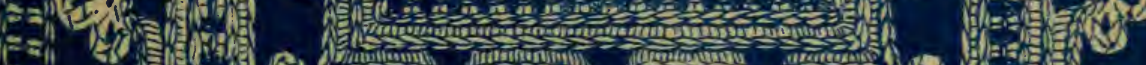

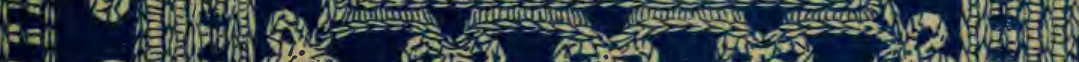

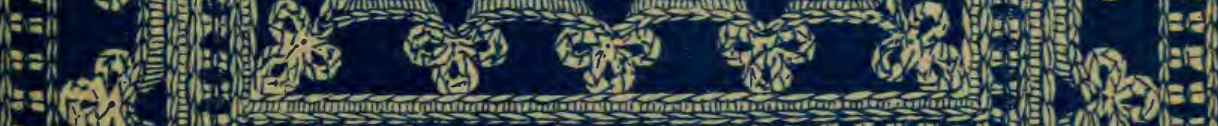
$x_{2}$ i ies 4 h

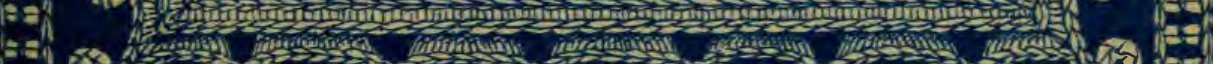
KE

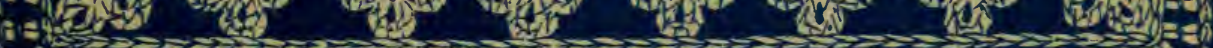
8ता का

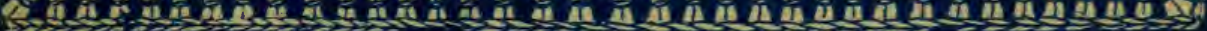





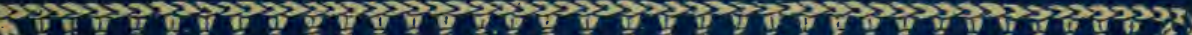

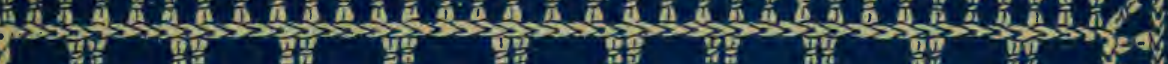

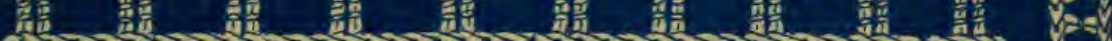

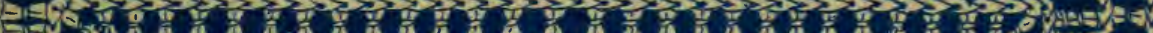

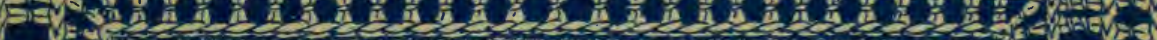

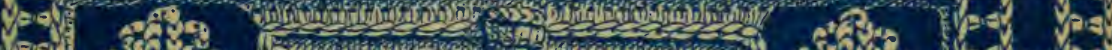

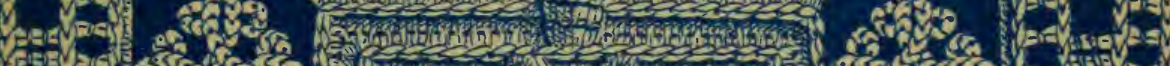

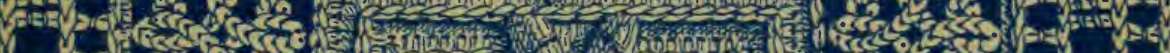

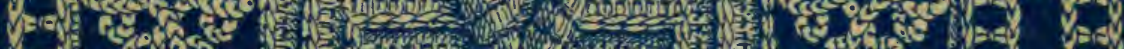

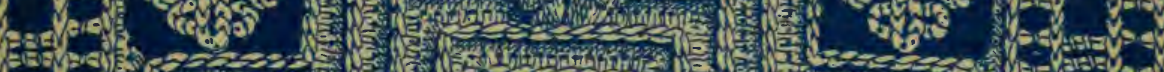

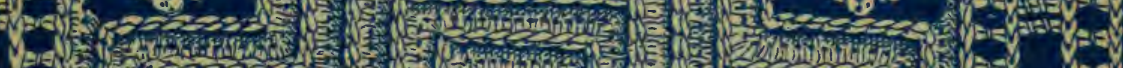

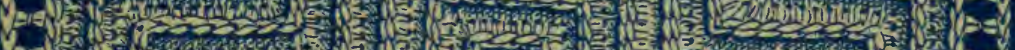

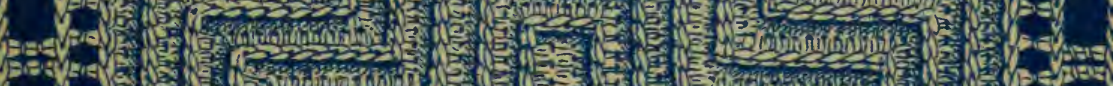

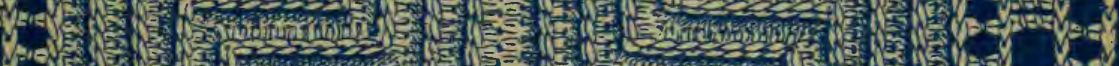

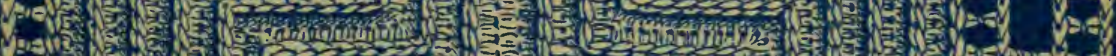
$68=1$.

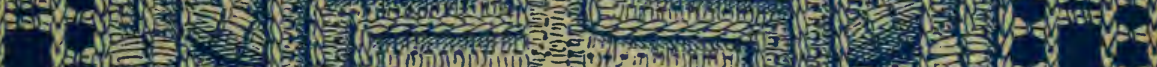
Q.

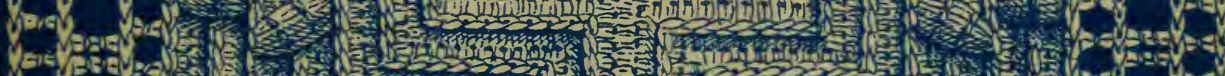
Fav

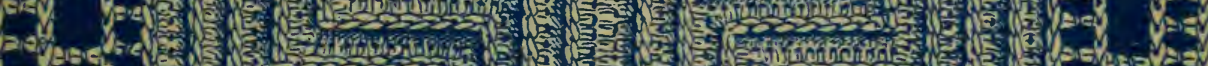

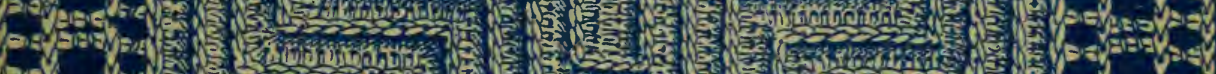

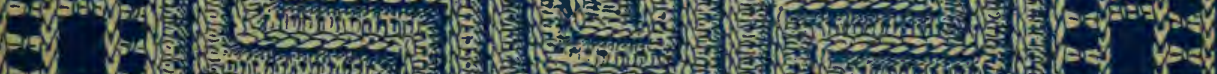

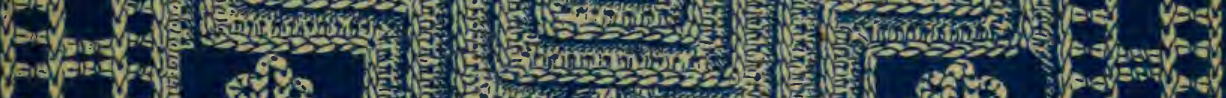

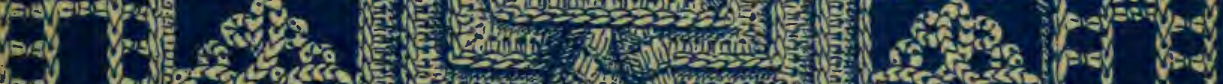

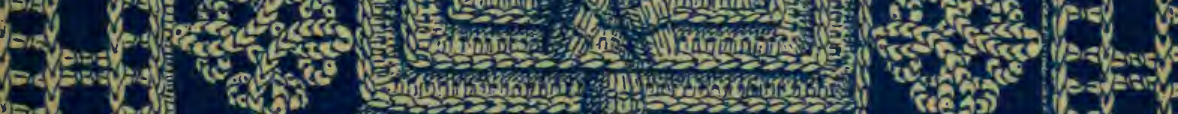

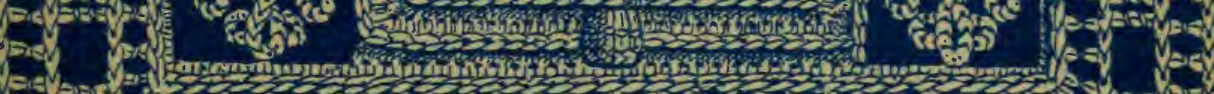

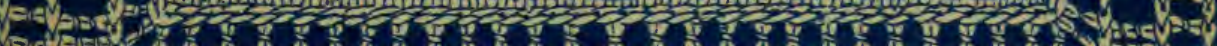

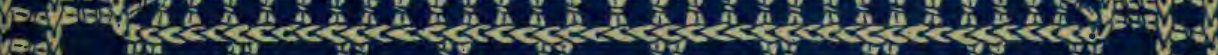

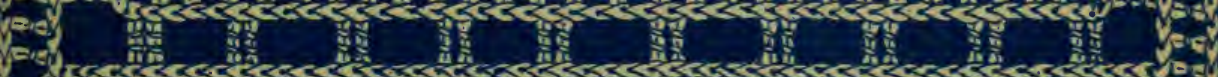

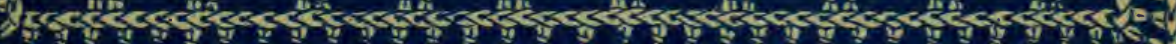

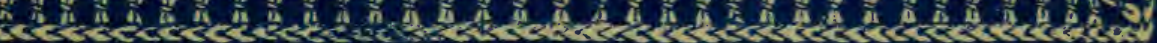





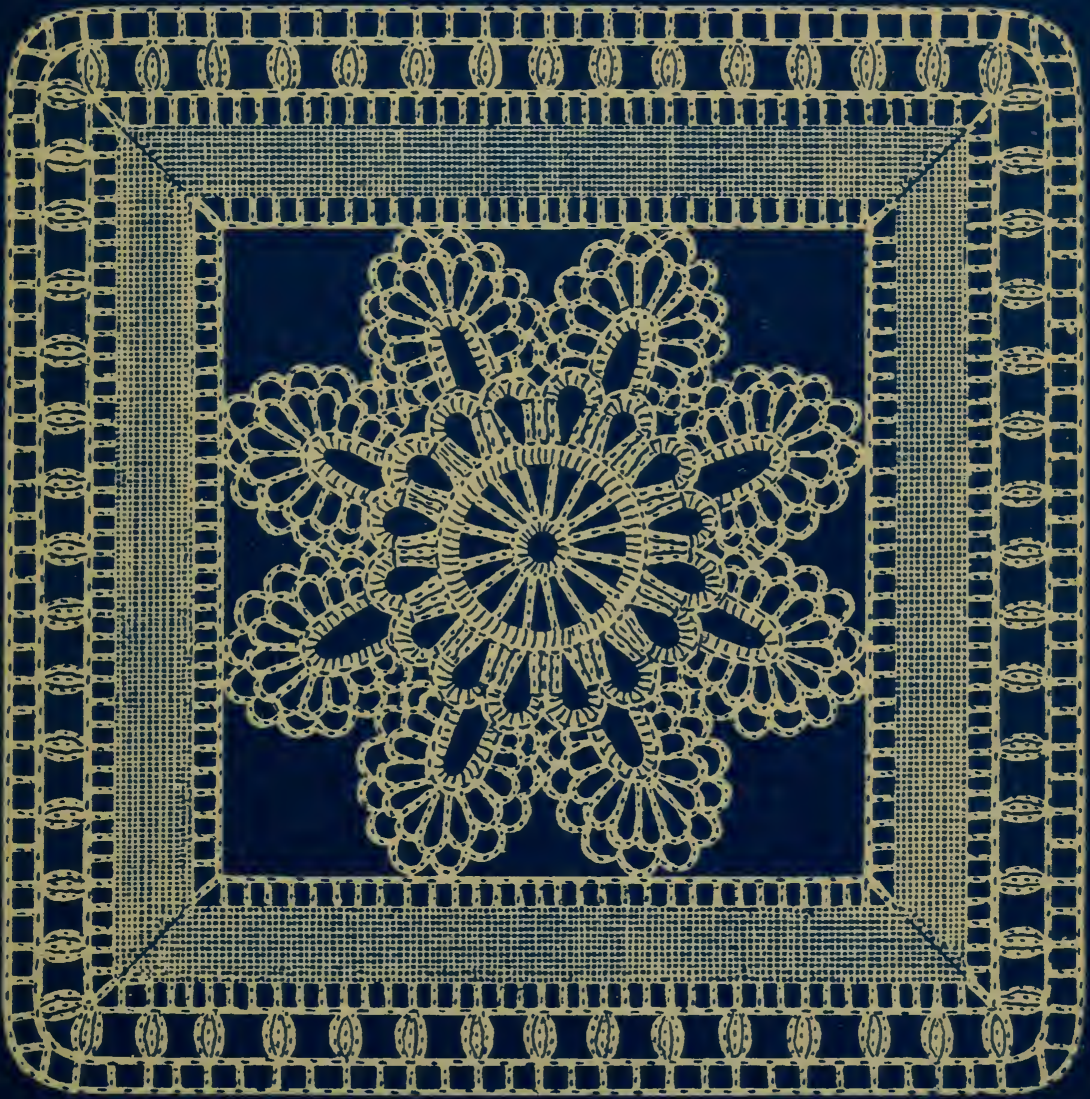





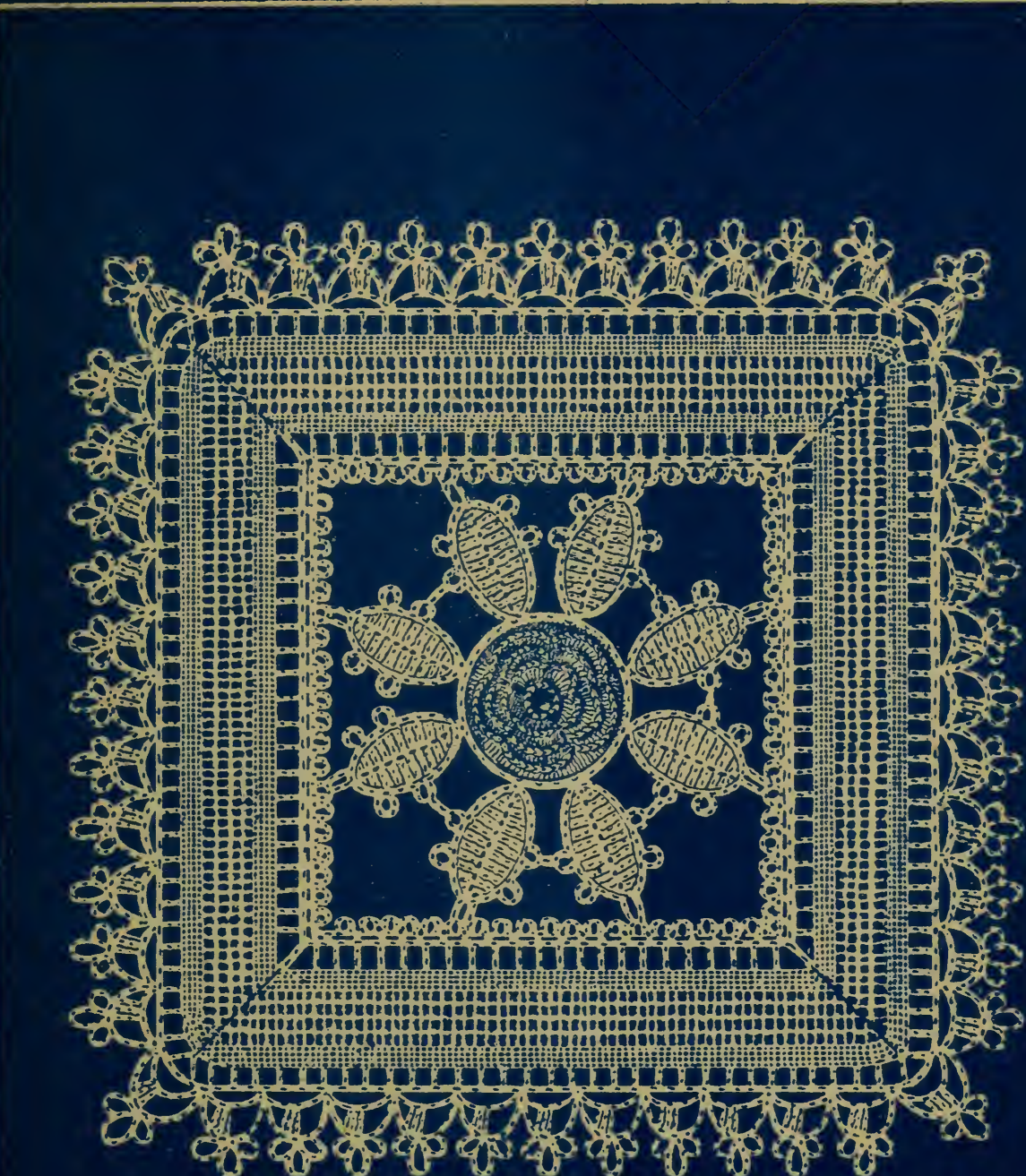





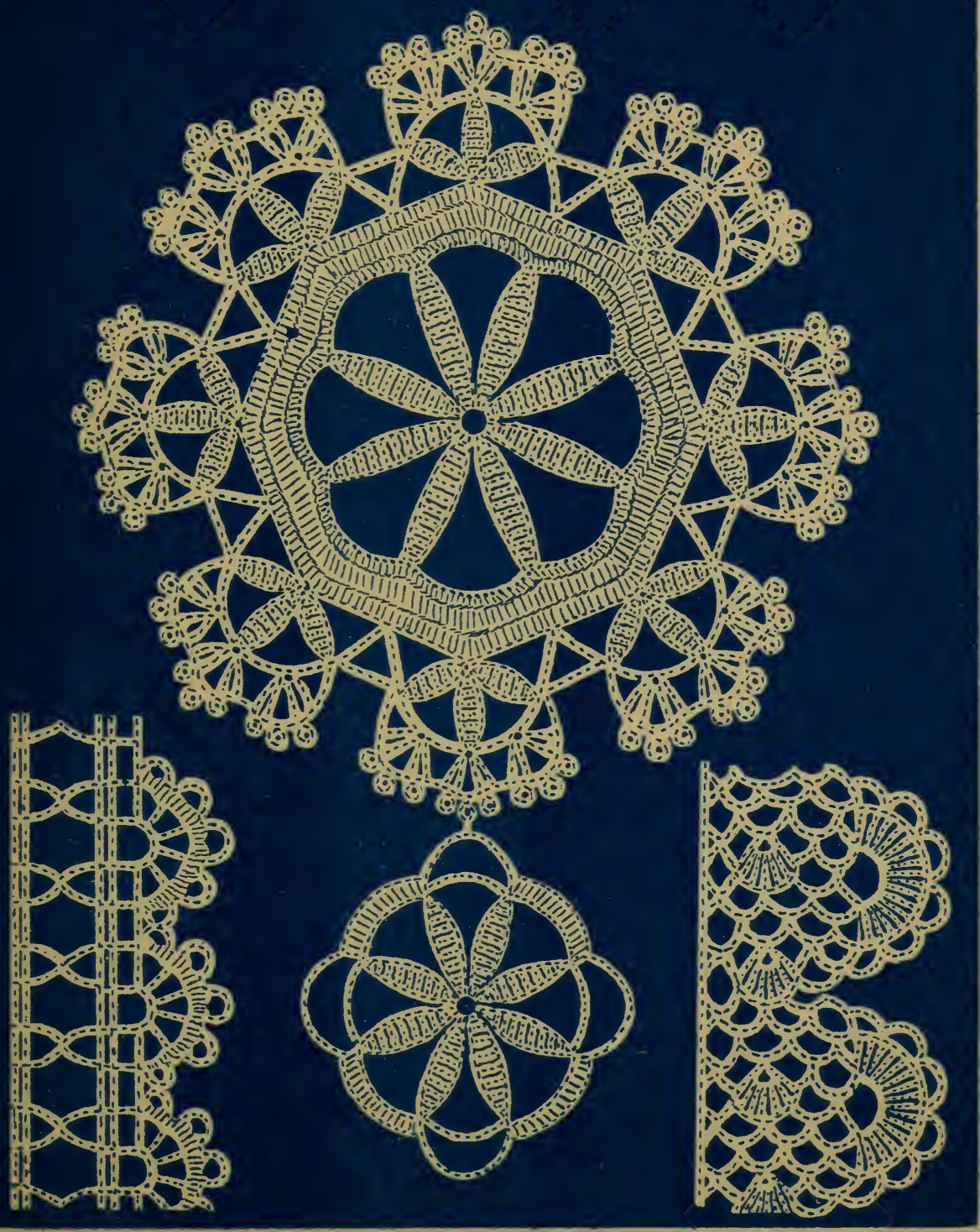





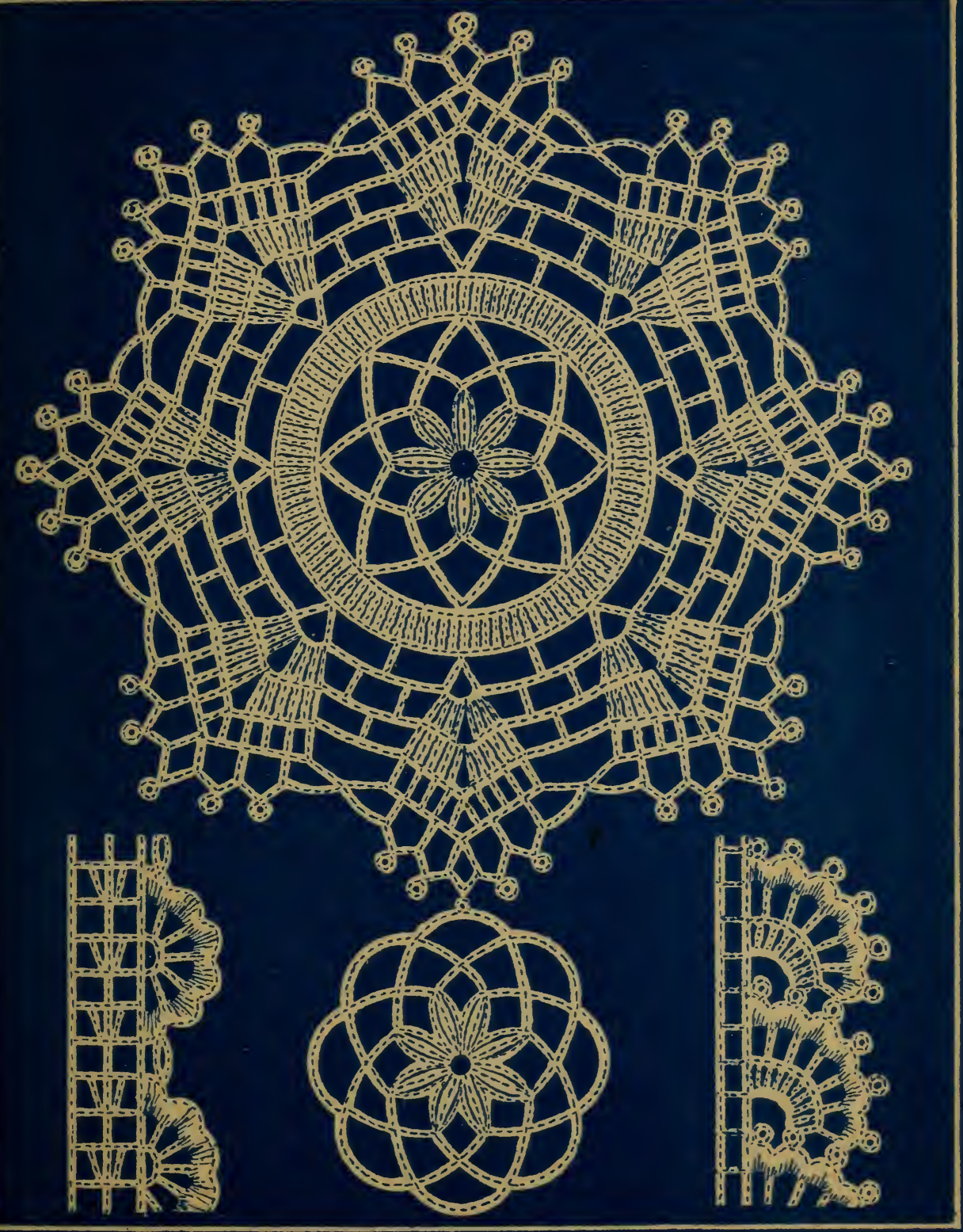




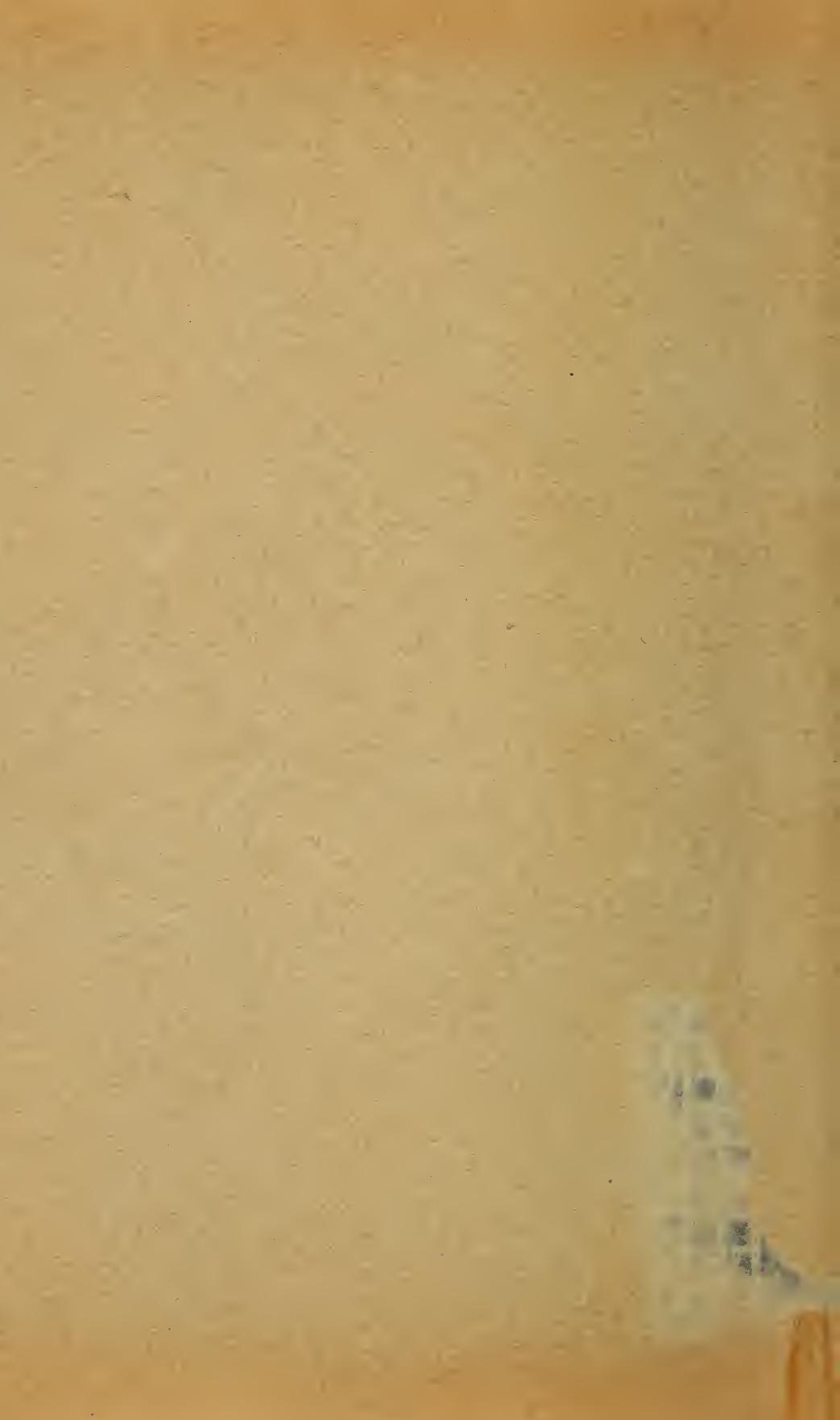




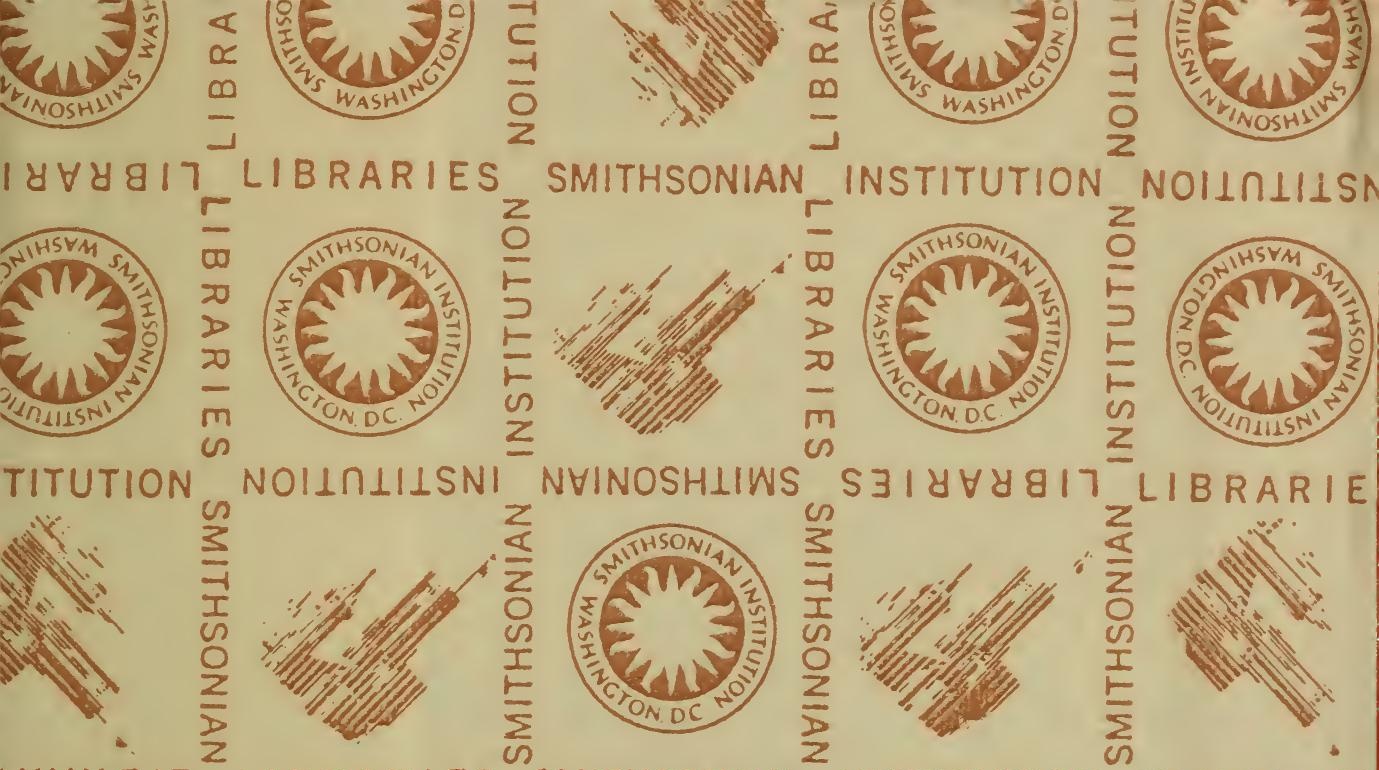

$18 \forall \forall 817$
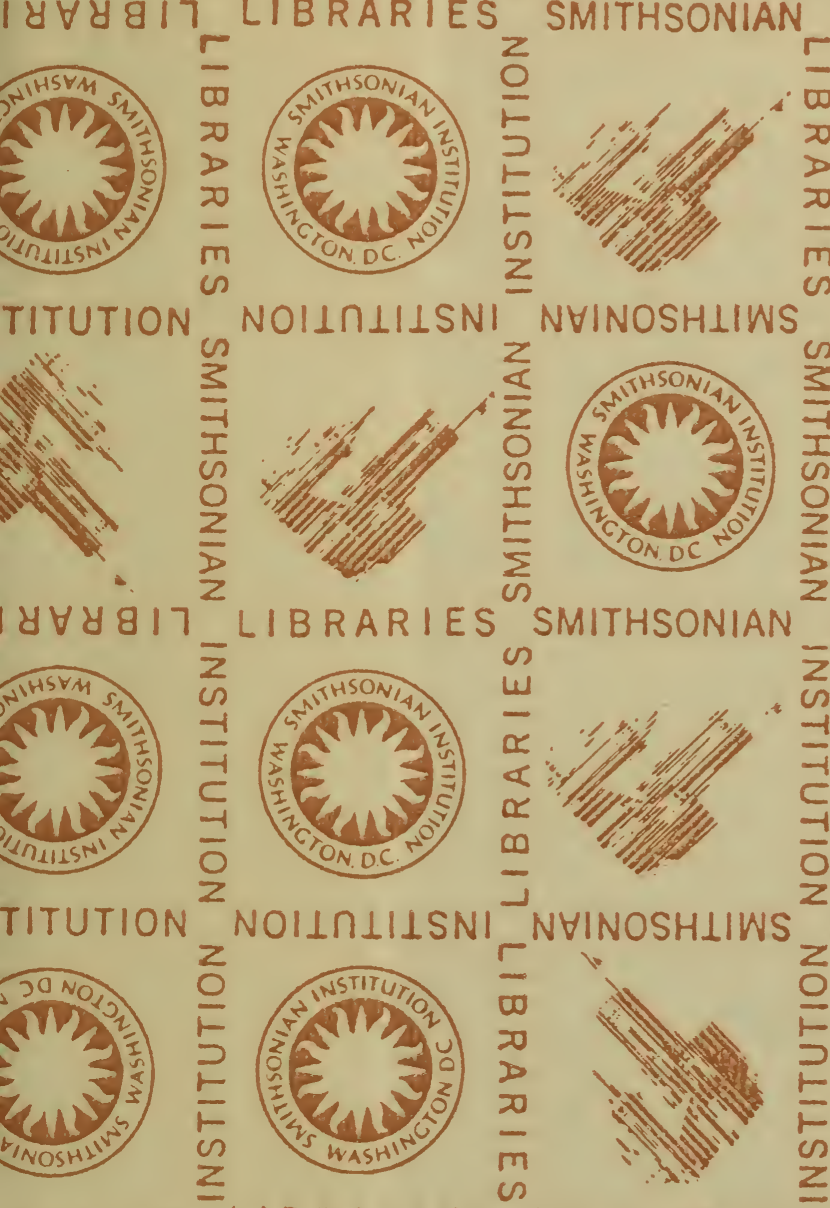

INSTITUTION
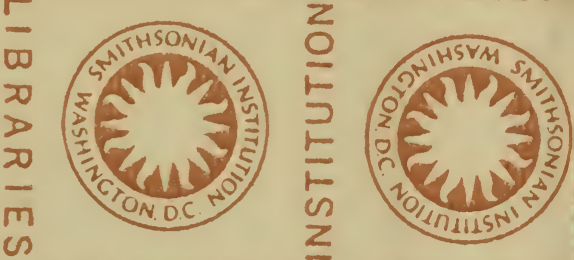

NHINOSHLIWS S $318 \forall \forall 917$
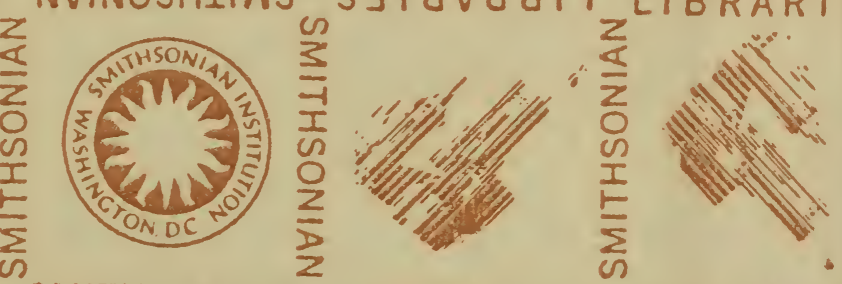

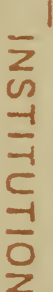

$\bar{z}$
-1
$\overline{1}$
$\bar{c}$
-1
$\overline{0}$

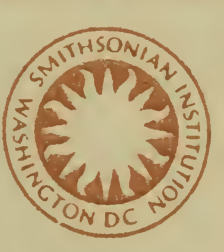

$\omega$
-
$\alpha$
$\alpha$
$\alpha$
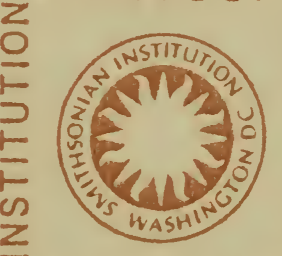

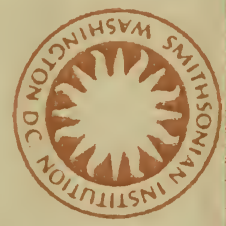

| BRARIE

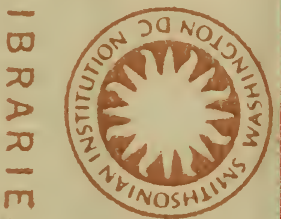

(s)

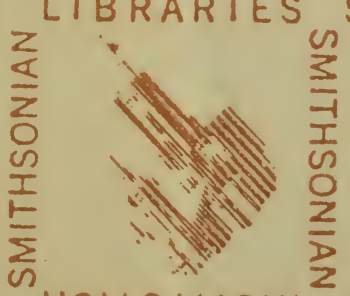

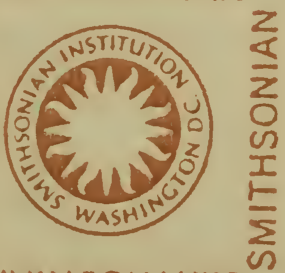

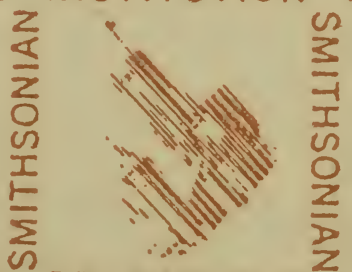

VOIINLIISN

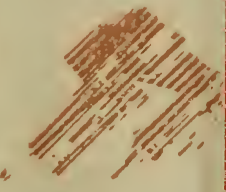

NOIIALILNI NHINOSHLIWS
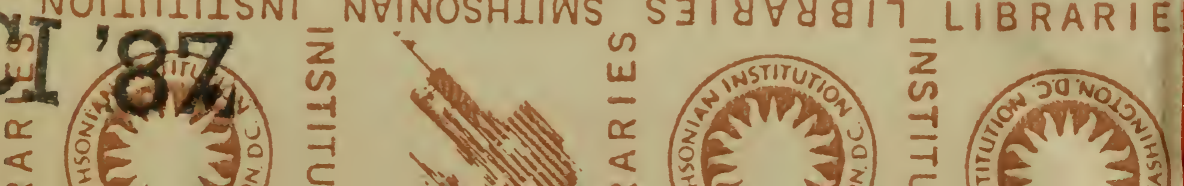
SMITHSONIAN INSTITUTION LIBRARIES

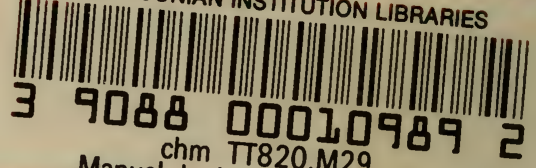
Manuel de dessins.M29

de dessins pour crochet. 